\title{
Nitridation Temperature Effect on Carbon Vanadium Oxynitrides for a Symmetric Supercapacitor
}

\author{
Ndeye M. Ndiaye ${ }^{1}$, Ndeye F. Sylla ${ }^{1}$, Balla D. Ngom ${ }^{2}$, Bridget K. Mutuma ${ }^{1}{ }^{(1)}$, \\ Julien K. Dangbegnon ${ }^{1}$, Sekhar C. Ray ${ }^{3}\left(\mathbb{D}\right.$ and Ncholu Manyala ${ }^{1, *(D)}$ \\ 1 Department of Physics, Institute of Applied Materials, SARChI Chair in Carbon Technology and Materials, \\ University of Pretoria, Pretoria 0028, South Africa; nmaty.ndiaye@gmail.com (N.M.N.); \\ ntoufasylla@gmail.com (N.F.S.); bridgetmutuma@gmail.com (B.K.M.); \\ dangbegnon01@googlemail.com (J.K.D.) \\ 2 Laboratoire de Photonique Quantique d'Energie et de NanoFabrication, Groupe de Physique du Solide et \\ Science des Materiaux, Departement de Physique FST-UCAD BP 5005 Dakar-Fan, Dakar 999066, Senegal; \\ bdngom@gmail.com \\ 3 Department of Physics, College of Science, Engineering and Technology, University of South Africa, \\ Private Bag X6, Florida 1710, Science Campus, Christiaan de Wet and Pioneer Avenue, Florida Park, \\ Johannesburg 1710, South Africa; raysc@unisa.ac.za \\ * Correspondence: ncholu.manyala@up.ac.za; Tel.: +27-12-420-3549; Fax: +27-12-420-2516
}

Received: 4 November 2019; Accepted: 4 December 2019; Published: 11 December 2019

\begin{abstract}
In this work, porous carbon-vanadium oxynitride $\left(\mathrm{C}-\mathrm{V}_{2} \mathrm{NO}\right)$ nanostructures were obtained at different nitridation temperature of 700,800 and $900{ }^{\circ} \mathrm{C}$ using a thermal decomposition process. The X-ray diffraction (XRD) pattern of all the nanomaterials showed a $\mathrm{C}-\mathrm{V}_{2} \mathrm{NO}$ single-phase cubic structure. The $\mathrm{C}-\mathrm{V}_{2} \mathrm{NO}$ obtained at $700{ }^{\circ} \mathrm{C}$ had a low surface area $\left(91.6 \mathrm{~m}^{2} \mathrm{~g}^{-1}\right)$, a moderate degree of graphitization, and a broader pore size distribution. The $\mathrm{C}-\mathrm{V}_{2} \mathrm{NO}$ obtained at $800^{\circ} \mathrm{C}$ displayed an interconnected network with higher surface area $\left(121.6 \mathrm{~m}^{2} \mathrm{~g}^{-1}\right)$ and a narrower pore size distribution. In contrast, at $900{ }^{\circ} \mathrm{C}$, the $\mathrm{C}-\mathrm{V}_{2} \mathrm{NO}$ displayed a disintegrated network and a decrease in the surface area $\left(113 \mathrm{~m}^{2} \mathrm{~g}^{-1}\right)$. All the synthesized $\mathrm{C}-\mathrm{V}_{2} \mathrm{NO}$ yielded mesoporous oxynitride nanostructures which were evaluated in three-electrode configuration using $6 \mathrm{M} \mathrm{KOH}$ aqueous electrolyte as a function of temperature. The $\mathrm{C}-\mathrm{V}_{2} \mathrm{NO} @ 800{ }^{\circ} \mathrm{C}$ electrode gave the highest electrochemical performance as compared to its counterparts due to its superior properties. These results indicate that the nitridation temperature not only influences the morphology, structure and surface area of the $\mathrm{C}-\mathrm{V}_{2} \mathrm{NO}$ but also their electrochemical performance. Additionally, a symmetric device fabricated from the $\mathrm{C}-\mathrm{V}_{2} \mathrm{NO} @ 800{ }^{\circ} \mathrm{C}$ displayed specific energy and power of $38 \mathrm{~W} \mathrm{~h} \mathrm{~kg}^{-1}$ and $764 \mathrm{~W} \mathrm{~kg}^{-1}$, respectively, at $1 \mathrm{~A} \mathrm{~g}^{-1}$ in a wide operating voltage of $1.8 \mathrm{~V}$. In terms of stability, it achieved $84.7 \%$ as capacity retention up to 10,000 cycles which was confirmed through the floating/aging measurement for up to $100 \mathrm{~h}$ at $10 \mathrm{~A} \mathrm{~g}^{-1}$. This symmetric capacitor is promising for practical applications due to the rapid and easy preparation of the carbon-vanadium oxynitride materials.
\end{abstract}

Keywords: carbon-vanadium oxynitride; mesoporous; pore size distribution; nitridation temperature; symmetric capacitor

\section{Introduction}

The growing demand for conversion of renewable energy systems and a foreseeable shortage of fossil fuels for usable energy is a major challenge for energy storage. However, many high-energy storage systems have also been developed to meet the generated energy efficiently for productive use and cost-effectiveness, such as batteries and supercapacitors [1,2]. Supercapacitors (SCs), also named ultracapacitors, have largely been studied in the field of energy storage. They exhibit a high 
power density, a longer cycling life, and safety as compared to batteries [3,4]. However, ultracapacitors possess low energy [5], and their improvement may be achieved by the synthesis of materials that display unique morphologies with high performance.

Typically, ultracapacitors can be classified into two types based on their charge storage mechanism: electric double-layer capacitors (EDLCs) and Faradaic capacitors [6,7]. EDLCs can store the charge in double-layer capacitance. The materials used are carbon-based active materials with high specific surface area (SSA), good electronic conductivity, good stability and low specific capacitance [6]. In pseudocapacitive or Faradaic capacitors, the charge storage mechanism is based on fast reversible redox reactions such as in metal oxides (MOs), metal hydroxides (MOHs) and conducting polymers (CPs) $[8,9]$.

For decades, metal oxides have been widely used for energy storage applications due to their high Faradaic activity and their variable oxidation states by adopting different structures [10]. Nevertheless, metal oxides suffer low SSA and low conductivity which leads to low specific power and low cyclic stability [11]. Thus, it is necessary to synthesize new electrode materials applicable in Faradaic capacitors. Recently, several achievements geared at improving the stability, conductivity and wettability of Faradaic materials have been reported such as the adoption of metal sulphides (MSs) [12], metal nitrides (MNs) [13] and metal oxynitride (MONs) [14]. For MNs, the oxygen $\left(\mathrm{O}^{2-}\right)$ atoms in the metal octahedral position were completely replaced by nitrogen $\left(\mathrm{N}^{3-}\right)$ atoms, while for the MONs (e.g., $\mathrm{M}=\mathrm{Ti}$ [15], $\mathrm{W}$ [16], Mo [17], $\mathrm{V}$ [18]), the replacement is partial which leads to the presence of some metal oxides [14].

Among the greatest recent achievements, vanadium oxynitride materials has been considered to be an excellent candidate due to their superior outstanding electrochemical properties due to multiple oxidation states $\left(\mathrm{V}^{5+}, \mathrm{V}^{4+}, \mathrm{V}^{3+}, \mathrm{V}^{2+}\right)$ leading to an excellent specific capacity, and the presence of some vanadium oxides. $\mathrm{VO}_{\mathrm{x}} \mathrm{N}_{\mathrm{y}}$ still suffers from poor rate performance, low specific surface area and aging effects [14,19]. However, most reports on vanadium oxynitride materials entail the use of vanadium oxide precursors such as $\mathrm{VO}_{2}$ or $\mathrm{V}_{2} \mathrm{O}_{5}$ resulting in the generation of aggregated $\mathrm{VO}_{\mathrm{x}} \mathrm{N}_{\mathrm{y}}$ particles owing to the low melting point of the vanadium oxides [20]. Consequently, this limits the electrochemical performance of these materials due to their low specific surface areas $[18,20]$. To overcome this drawback, an appropriate and efficient vanadium precursor is required.

Although various researchers have reported on the use of vanadium chloride and vanadium oxychloride precursors to obtain good crystalline $\mathrm{VO}_{\mathrm{x}} \mathrm{N}_{\mathrm{y}}$ nanostructures $[18,21]$, a controlled working environment is required due to the high reactivity and toxicity of the chlorides [22]. Ammonium metavanadate $\left(\mathrm{NH}_{4} \mathrm{VO}_{3}\right)$ is less toxic, less corrosive and safer compared to the chloride-based precursors and thus, a suitable alternative for the preparation of $\mathrm{VO}_{\mathrm{x}} \mathrm{N}_{\mathrm{y}}$ materials. Moreover, a recent approach on the use of organic precursors in the growth of oxynitride materials has resulted in a controlled particle formation, generation of a crystalline structure, as well as the ability to tune the specific surface area of the final product [23]. In this regard, polyvinylpyrrolidone, urea, cyanamide and melamine are commonly used organic precursors as they serve as both carbon and nitrogen sources with the melamine providing a higher nitrogen and carbon contents. For instance, Cheng et al. [20] studied $\mathrm{VN}_{1.02} \mathrm{O}_{0.1}$ material by calcining a mixture of melamine and $\mathrm{V}_{2} \mathrm{O}_{5}$ xerogel in a furnace at $800{ }^{\circ} \mathrm{C}$ under $\mathrm{N}_{2}$ atmosphere. They obtained a carbon content of $52.6 \%$ and a nitrogen content of $22.6 \%$ after melamine decomposition [20]. The presence of carbon in the vanadium oxynitride matrix can greatly influence the specific surface area, structure and morphology of the $\mathrm{VO}_{\mathrm{x}} \mathrm{N}_{\mathrm{y}}$ and, as a result, improve their electrochemical capacitance [22]. Recently, a different approach of tuning nitridation temperature of oxynitride based-materials has been proposed to enhance their properties. For example, Jacke et al. [24] demonstrated the dependence of the conductivity of lithium-phosphorous oxynitride films on temperature (at room temperature, $200^{\circ} \mathrm{C}$ and $300{ }^{\circ} \mathrm{C}$ ). They concluded that an increased amount of nitrogen revealed an improvement in the conductivity of the oxynitride materials at high temperatures [24]. To the best of our knowledge, to date no reports on the evaluation of vanadium 
oxynitride materials at different nitridation temperature for supercapacitors have been found in the literature.

This study presents an in-depth understanding of how nitridation temperature influences the physical and electrochemical properties of $\mathrm{C}-\mathrm{V}_{2} \mathrm{NO}$ nanostructures. At $700{ }^{\circ} \mathrm{C}$, a low surface area and less crystalline $\mathrm{C}-\mathrm{V}_{2} \mathrm{NO}$ nanostructure was obtained. In contrast, at 800 and $900{ }^{\circ} \mathrm{C}$, the $\mathrm{C}-\mathrm{V}_{2} \mathrm{NO}$ nanostructures showed higher specific surface area and smaller pore size distribution. The effect of the different nitridation temperature was associated with the electrochemical performances of the $\mathrm{C}-\mathrm{V}_{2} \mathrm{NO}$ electrodes evaluated in $6 \mathrm{M} \mathrm{KOH}$ aqueous electrolyte. To confirm the electrochemical properties of the material, a symmetric supercapacitor $\left(\mathrm{C}-\mathrm{V}_{2} \mathrm{NO} / / \mathrm{C}-\mathrm{V}_{2} \mathrm{NO}\right)$ was assembled using a $\mathrm{C}-\mathrm{V}_{2} \mathrm{NO} @ 800{ }^{\circ} \mathrm{C}$ in both positive and negative potential windows. In a wide voltage of $1.8 \mathrm{~V}$, the symmetric device exhibited a specific energy and specific power of $38 \mathrm{~W} \mathrm{~h} \mathrm{~kg}^{-1}$ and $764 \mathrm{~W} \mathrm{~kg}^{-1}$ at $1 \mathrm{~A} \mathrm{~g}^{-1}$, respectively. The $\left(\mathrm{C}-\mathrm{V}_{2} \mathrm{NO} / / \mathrm{C}-\mathrm{V}_{2} \mathrm{NO}\right)$ showed $84.7 \%$ capacity retention at 10,000 th cycles and excellent voltage holding stability up to $100 \mathrm{~h}$ at a high specific current.

\section{Experimental}

\subsection{Synthesis of $C-V_{2} N O$ Nanomaterials by Thermal Decomposition Technique}

Scheme 1 presents the diagram illustrating the procedure adopted to synthesize the $\mathrm{C}-\mathrm{V}_{2} \mathrm{NO}$ nanomaterials at a nitridation temperature of $700{ }^{\circ} \mathrm{C}$. The $\mathrm{C}-\mathrm{V}_{2} \mathrm{NO}$ nanomaterials were synthesized by thermal decomposition method using ammonium metavanadate $\left(\mathrm{NH}_{4} \mathrm{VO}_{3}, 99 \%\right)$ and melamine $\left(\mathrm{C}_{3} \mathrm{H}_{6} \mathrm{~N}_{6}, 99 \%\right)$ with a mass loading ratio of $1: 10$. The preparation details of the $\mathrm{C}-\mathrm{V}_{2} \mathrm{NO}$ was reported in our previous study by Ndiaye et al. [25]. Briefly the $\mathrm{NH}_{4} \mathrm{VO}_{3}$ and $\mathrm{C}_{3} \mathrm{H}_{6} \mathrm{~N}_{6}$ powders were mixed in an agate mortar with a few drops of ethanol $\left(\mathrm{CH}_{3} \mathrm{CH}_{2} \mathrm{OH}, 99 \%\right)$ to make a homogeneous slurry. This was inserted into a quartz tube furnace and heated to $700{ }^{\circ} \mathrm{C}$ at a heating rate of $18{ }^{\circ} \mathrm{C} \mathrm{min}^{-1}$ before being kept at that temperature for $2 \mathrm{~h}$ under a stream of nitrogen $\left(\mathrm{N}_{2}\right)$ gas flow. After cooling down to room temperature, the final product was obtained and labelled as $\mathrm{C}-\mathrm{V}_{2} \mathrm{NO} @ 700{ }^{\circ} \mathrm{C}$. The same method has been used to prepare $\mathrm{C}-\mathrm{V}_{2} \mathrm{NO}$ nanomaterials at $800{ }^{\circ} \mathrm{C}$ and $900^{\circ} \mathrm{C}$.

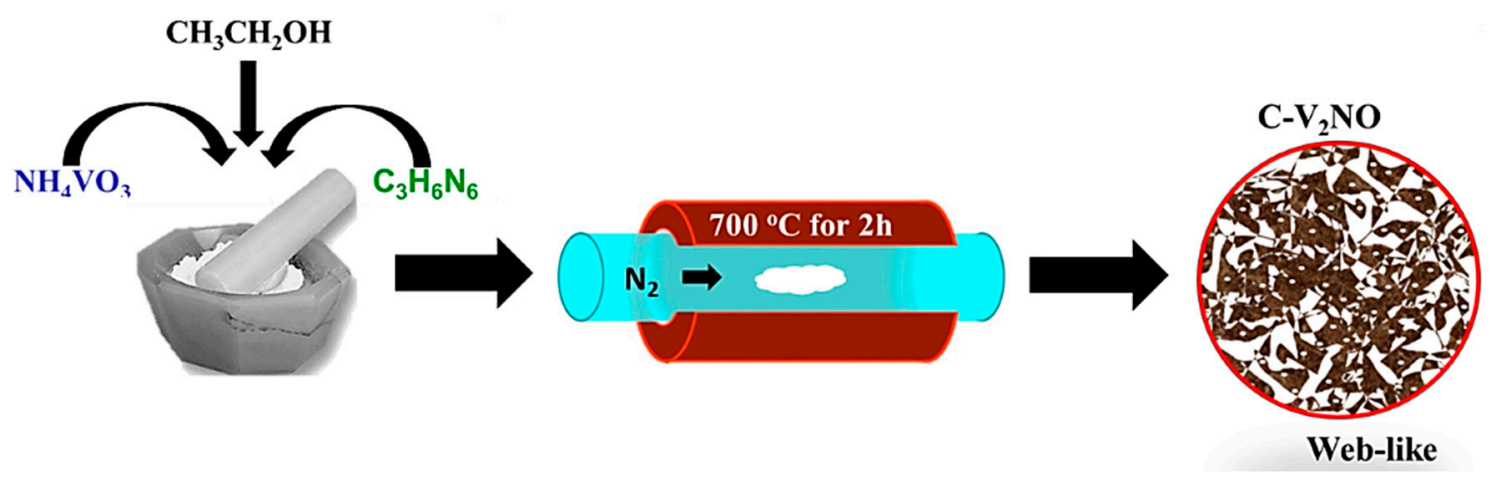

Scheme 1. : Preparation steps of carbon-vanadium oxynitride at $700{ }^{\circ} \mathrm{C}$.

\subsection{Structure, Morphology and Composition Characterization}

X-ray diffraction (XRD) analysis of as-prepared $\mathrm{C}-\mathrm{V}_{2} \mathrm{NO}$ nanomaterials was studied using a cobalt X-ray source at $50 \mathrm{~mA}$ and $35 \mathrm{kV}$ by a XPERT-PRO diffractometer (PANalytical BV, Amsterdam, Netherlands) with $\theta / 2 \theta$ geometry in the range from $10-90^{\circ}$. Raman spectroscopy analysis of the materials were operated using a WITec confocal Raman microscope (WITec alpha300 RAS+) (WITec, Ulm, Germany). A field-emission scanning electron microscope of a Zeiss Ultra plus 55 field (FE-SEM) (Akishima, Japan) was used to investigate the morphology of the materials and the elemental mapping operated at a voltage of $2.0 \mathrm{kV}$. Transmission electron microscopy (TEM) analysis was carried out at $200 \mathrm{kV}$ on a JEOL JEM-2100F microscope (Akishima-shi, Japan). 
X-ray photoelectron spectroscopy (XPS, Thermo Fisher, Waltha, MA, USA, K-alpha) was used to study the composition of the materials with a monochromatic $\mathrm{Al}-\mathrm{K} \alpha$ radiation. The porosimetry tests of the $\mathrm{C}-\mathrm{V}_{2} \mathrm{NO}$ nanomaterials were evaluated with nitrogen adsorption-desorption isotherms at -196 ${ }^{\circ} \mathrm{C}$ using a Micromeritics ASAP 2020 (Tristar, Norcross, GA, USA). The specific surface area values of the materials were obtained by the Brunauer-Emmett-Teller (BET) analysis using the adsorption branch in the relative pressure range $(\mathrm{P} / \mathrm{P} 0)$ of $0.01-1.0$.

\subsection{Electrochemical Characterization of $C-V_{2} N O$ Electrodes}

A Bio-Logic VMP-300 (Knoxville TN, USA) potentiostat were used to evaluate the electrochemical measurements (three- and two-electrode configurations) of the $\mathrm{C}-\mathrm{V}_{2} \mathrm{NO}$ electrodes at room temperature. The $\mathrm{C}-\mathrm{V}_{2} \mathrm{NO}$ electrodes were investigated by mixing weighed amounts of $\mathrm{C}-\mathrm{V}_{2} \mathrm{NO}$ active material, carbon black additive and polyvinylidene difluoride (PVDF) binder in a mass ratio of 80:10:10 with $\mathrm{N}$-methylpyrrolidone (NMP) as a solvent. The slurry was applied on a clean nickel foam (NiF) with a 3D scaffold template as a current collector. The electrodes were kept at $60^{\circ} \mathrm{C}$ in an electric oven overnight to ensure a complete evaporate of the $\mathrm{NMP} . \mathrm{Ag} / \mathrm{AgCl}(3 \mathrm{M} \mathrm{KCl}$ saturated) was used as reference electrode, a glassy carbon plate as counter electrode in a $6 \mathrm{M} \mathrm{KOH}$ aqueous electrolyte. The $\mathrm{C}-\mathrm{V}_{2} \mathrm{NO}$ electrodes were used as working electrodes to evaluate the electrochemical performance.

The measurements of the cyclic voltammetry (CV) and galvanostatic charge-discharge (GCD) were studied to determine the behaviour, the stable working potential and to calculate the specific capacity and the stability test of the electrodes, respectively. The specific capacity $\left(\mathrm{Q}_{\mathrm{S}}, \mathrm{mA} \mathrm{h} \mathrm{g}^{-1}\right)$ of the electrodes' materials was calculated using Equation (1) [26].

$$
Q=\frac{I_{d} \times t_{D}}{3.6}
$$

where $I_{d}$ is defined as the specific current measured in $\mathrm{A} \mathrm{g}^{-1}$ and $t_{D}$ is the time in second (s) for a complete discharge cycle.

The specific energy $\left(E_{d}, \mathrm{~W} \mathrm{~h} \mathrm{~kg}^{-1}\right)$ and the specific power, $\left(P_{d}, \mathrm{~W} \mathrm{~kg}^{-1}\right)$ of the $\mathrm{C}-\mathrm{V}_{2} \mathrm{NO} / / \mathrm{C}-\mathrm{V}_{2} \mathrm{NO}$ device were calculated using Equations (2) and (3) at different specific currents [27].

$$
\begin{gathered}
E_{d}\left(W h k^{-1}\right)=\frac{I_{d}}{3.6} \int V(t) d t \\
P_{d}\left(W k^{-1}\right)=3600 \frac{E_{D}}{t_{D}}
\end{gathered}
$$

where $I_{d}\left(\mathrm{~A} \mathrm{~g}^{-1}\right)$ represents the specific current, $t_{D}(\mathrm{~s})$ is called discharge time from the GCD curve, and $V(\mathrm{~V})$ is the voltage of the symmetric capacitor.

The measurements of the electrochemical impedance were carried out to study the conductivity and capacitive properties of the electrodes from $100 \mathrm{kHz}$ to $10 \mathrm{mHz}$ using an open circuit voltage.

\section{Results and Discussion}

XRD analysis results of the carbon-vanadium oxynitride nanostructures synthesized at 700, 800 and $900{ }^{\circ} \mathrm{C}$, respectively, are presented in Figure 1 The XRD patterns of the materials showed three diffraction peaks confirming the crystallinity of the material. The diffraction peaks are located at $2 \theta$ value of $44.0^{\circ}, 51^{\circ}$ and $75.5^{\circ}$ corresponding to the (111), (200) and (220) crystallographic planes, respectively. The XRD pattern of the nanomaterials shows $\mathrm{C}-\mathrm{V}_{2} \mathrm{NO}$ cubic nanostructure using the matching inorganic crystal structure Database (ICSD) card \#43182 [25]. The peak intensity of the $\mathrm{C}-\mathrm{V}_{2} \mathrm{NO}$ was found to increase with nitridation temperature indicating an increase in crystallinity. Indeed, the peaks of $\mathrm{C}-\mathrm{V}_{2} \mathrm{NO} @ 800^{\circ} \mathrm{C}$ and $\mathrm{C}-\mathrm{V}_{2} \mathrm{NO} @ 900{ }^{\circ} \mathrm{C}$ were narrower and much pronounced than the ones for $\mathrm{C}-\mathrm{V}_{2} \mathrm{NO} @ 700{ }^{\circ} \mathrm{C}$. However, the diffraction peak of carbon was not observed in Figure 1. This is due to the amorphous nature of the carbon in the materials. 


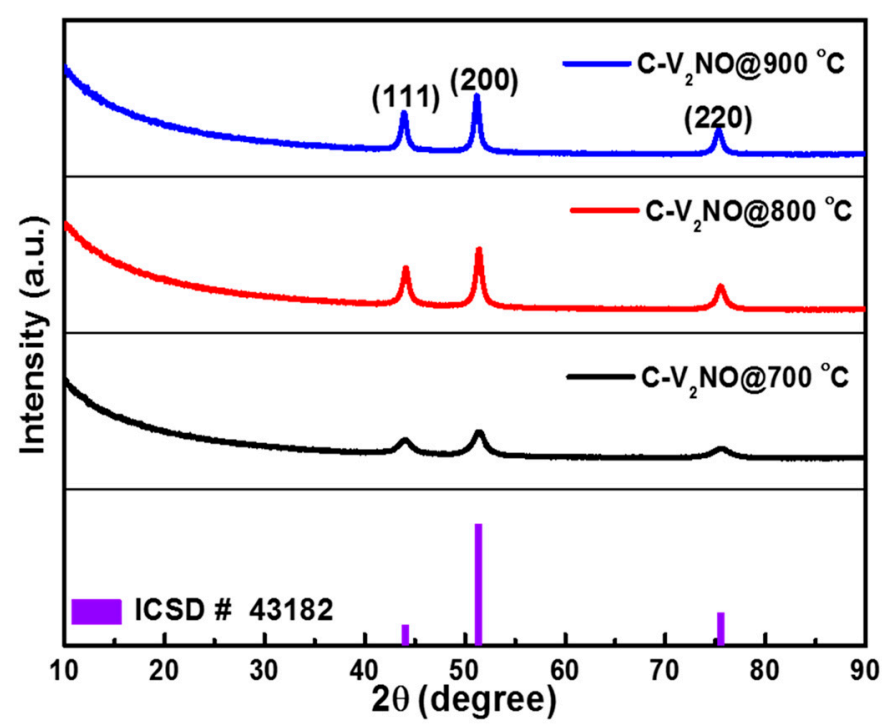

Figure 1. The X-ray diffraction (XRD) patterns of the $\mathrm{C}-\mathrm{V}_{2} \mathrm{NO}$ materials grown at 700,800 and $900{ }^{\circ} \mathrm{C}$.

The existence of amorphous carbon in the nanomaterials was nonetheless further confirmed from the Raman spectra as shown in Figure 2 with the characteristic D, G and D' bands. These three bands are attributed to carbonaceous material present in the $\mathrm{C}-\mathrm{V}_{2} \mathrm{NO}$ nanostructures at different nitridation temperatures. The $\mathrm{D}$ peak position was observed at $\left(1346-1373 \mathrm{~cm}^{-1}\right)$ as indicated in Table 1 and is associated to the defects existing in the carbon lattice structure $[28,29]$. The $G$ peak position observed at $\left(1585-1593 \mathrm{~cm}^{-1}\right)$ is related to the vibration modes of the graphitic sp ${ }^{2}$ carbon present $[28,30]$. A small shoulder was observed near the $G$ peak suggesting a graphene-like carbon present in the $\mathrm{C}-\mathrm{V}_{2} \mathrm{NO}$ nanomaterial. The $\mathrm{D}^{\prime}$ peak is ascribed to the lattice vibration mode of the $\mathrm{G}$ peak at the surface of the carbon structure [31,32]. A similar $\mathrm{D}^{\prime}$ peak has also been observed in boron carbon oxynitride films due to lattice distortions [33].

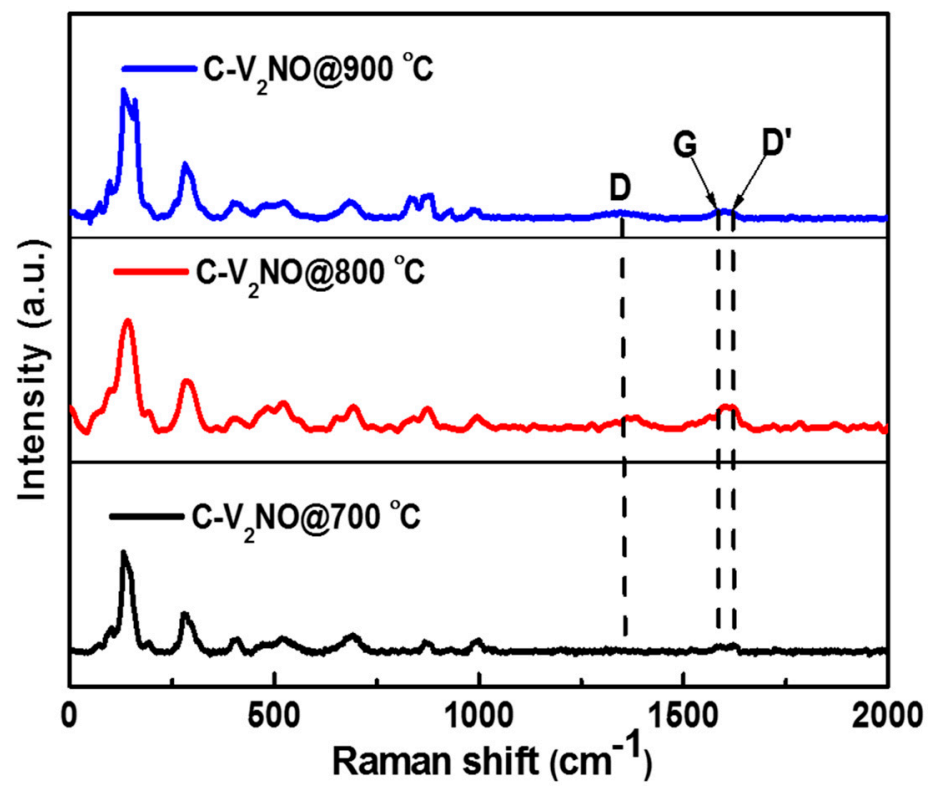

Figure 2. The Raman spectra of the $\mathrm{C}-\mathrm{V}_{2} \mathrm{NO}$ materials grown at 700,800 and $900{ }^{\circ} \mathrm{C}$.

The high $\mathrm{I}_{\mathrm{D}} / \mathrm{I}_{\mathrm{G}}$ ratio of the $\mathrm{C}-\mathrm{V}_{2} \mathrm{NO} @ 800{ }^{\circ} \mathrm{C}$ recorded in Table 1 suggests that the presence of defects could result from the nitrogen incorporated in the carbon lattice and also the strong interaction between the metal oxynitride and the carbon. The lower degree of graphitization (highest $\mathrm{I}_{\mathrm{D}} / \mathrm{I}_{\mathrm{G}}$ ratio) in the $\mathrm{C}-\mathrm{V}_{2} \mathrm{NO} @ 800{ }^{\circ} \mathrm{C}$ can contribute to high electrochemical capacity $[34,35]$. The Raman spectra 
for the $\mathrm{C}-\mathrm{V}_{2} \mathrm{NO}$ nanomaterials synthesized at 700, 800 and $900{ }^{\circ} \mathrm{C}$ also displayed Raman bands at wavenumbers of $142,145,192,285,479,520.7,693,822,873$, and $995 \mathrm{~cm}^{-1}$ as seen in Figure 2 which can be attributed to the cubic symmetry vibration mode of the vanadium oxynitride [36] and the vanadium oxides (e.g., $\mathrm{VO}_{2}$ and $\mathrm{V}_{2} \mathrm{O}_{5}$ ) stretching mode [25].

Table 1. $\mathrm{D}, \mathrm{G}, \mathrm{D}^{\prime}$ band positions and $\mathrm{I}_{\mathrm{D}} / \mathrm{I}_{\mathrm{G}}$ ratio of the $\mathrm{C}-\mathrm{V}_{2} \mathrm{NO}$ samples.

\begin{tabular}{|c|c|c|c|c|}
\hline Material & $\begin{array}{l}\text { D Peak Position } \\
\left(\mathrm{cm}^{-1}\right)\end{array}$ & $\begin{array}{l}\text { G Peak Position } \\
\left(\mathrm{cm}^{-1}\right)\end{array}$ & $\begin{array}{l}D^{\prime} \text { Peak Position } \\
\quad\left(\mathrm{cm}^{-1}\right)\end{array}$ & $\begin{array}{c}\mathrm{I}_{\mathrm{D}} / \mathrm{I}_{\mathrm{G}} \text { Ratio } \\
( \pm \mathbf{0 . 0 3 )}\end{array}$ \\
\hline $\mathrm{C}-\mathrm{V}_{2} \mathrm{NO} @ 700{ }^{\circ} \mathrm{C}$ & 1349 & 1585 & 1611 & 0.47 \\
\hline $\mathrm{C}-\mathrm{V}_{2} \mathrm{NO} @ 800{ }^{\circ} \mathrm{C}$ & 1373 & 1593 & 1621 & 0.84 \\
\hline $\mathrm{C}-\mathrm{V}_{2} \mathrm{NO} @ 900{ }^{\circ} \mathrm{C}$ & 1346 & 1588 & 1618 & 0.56 \\
\hline
\end{tabular}

The morphological analysis of the $\mathrm{C}-\mathrm{V}_{2} \mathrm{NO}$ nanomaterials synthesized at different temperatures is presented in Figure 3 at low and high magnification. The morphologies of the $\mathrm{C}-\mathrm{V}_{2} \mathrm{NO}$ nanomaterials at different temperatures exhibited an agglomeration of cubic structures which showed a web-like morphology on the surface with irregular cavities (Figure 3a,c,e). At higher magnifications, $\mathrm{C}-\mathrm{V}_{2} \mathrm{NO} @ 700{ }^{\circ} \mathrm{C}$ shows densely packed nanoparticles that are non-uniformly distributed (Figure $3 \mathrm{~b}$ ). In contrast, the surface morphology of the $\mathrm{C}-\mathrm{V}_{2} \mathrm{NO} @ 800^{\circ} \mathrm{C}$ shows interconnecting particles to form a web-like structure (Figure $3 \mathrm{~d}$ ). At $900{ }^{\circ} \mathrm{C}$, a disintegrated network of the $\mathrm{C}-\mathrm{V}_{2} \mathrm{NO}$ is observed (Figure 3f). In the $\mathrm{C}-\mathrm{V}_{2} \mathrm{NO} @ 800^{\circ} \mathrm{C}$, it can be seen clearly that the porous cavities can penetrate deep into the material with a non-uniform distribution compared to the $\mathrm{C}-\mathrm{V}_{2} \mathrm{NO}$ nanomaterials obtained at $700{ }^{\circ} \mathrm{C}$ and $900^{\circ} \mathrm{C}$.

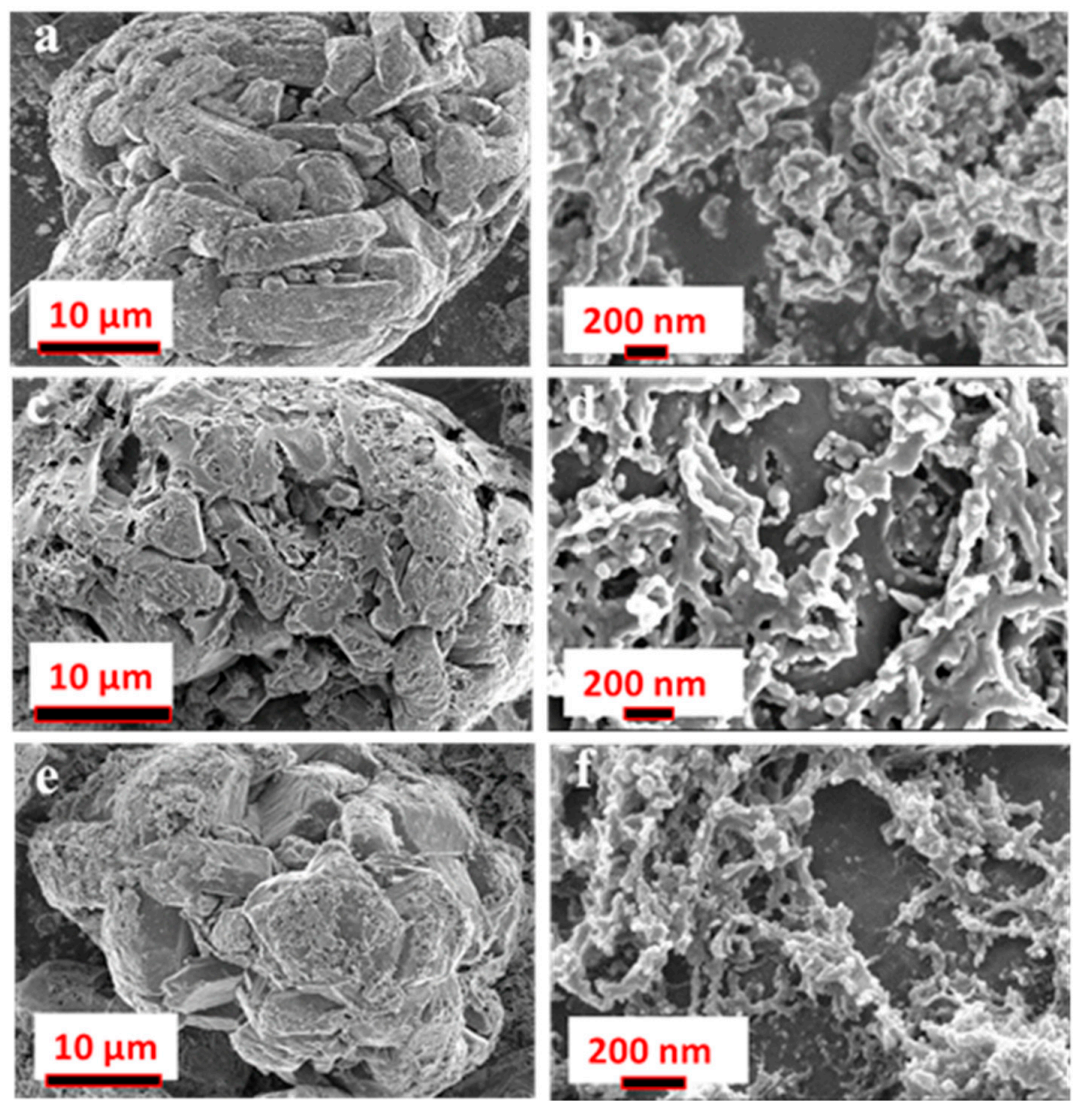

Figure 3. Scanning electron microscope (SEM) images at low and high magnification of the synthesized $(\mathbf{a}, \mathbf{b}) \mathrm{C}-\mathrm{V}_{2} \mathrm{NO} @ 700{ }^{\circ} \mathrm{C},(\mathbf{c}, \mathbf{d}) \mathrm{C}-\mathrm{V}_{2} \mathrm{NO} @ 800{ }^{\circ} \mathrm{C}$ and $(\mathbf{e}, \mathbf{f}) \mathrm{C}-\mathrm{V}_{2} \mathrm{NO} @ 900{ }^{\circ} \mathrm{C}$ nanomaterials. 
In order to investigate the composition element at different nitridation, energy-dispersive $\mathrm{X}$-ray spectroscopy (EDX) analysis was carried out to determine the elements present in the materials. The elemental mapping displayed the distinct element distribution in the $\mathrm{C}-\mathrm{V}_{2} \mathrm{NO} @ 700{ }^{\circ} \mathrm{C}, \mathrm{C}-\mathrm{V}_{2} \mathrm{NO} @ 800{ }^{\circ} \mathrm{C}$ and $\mathrm{C}-\mathrm{V}_{2} \mathrm{NO} @ 900{ }^{\circ} \mathrm{C}$ nanostructures as shown in Figure 4. This shows the presence of carbon (C), nitrogen $(\mathrm{N})$, vanadium $(\mathrm{V})$ and oxygen $(\mathrm{O})$ atoms in all the $\mathrm{C}-\mathrm{V}_{2} \mathrm{NO}$ nanomaterials. As seen in Figure $4 \mathrm{a}-\mathrm{c}$, a homogeneous distribution of the elements in the overall structure has been observed which confirms that the $\mathrm{C}-\mathrm{V}_{2} \mathrm{NO}$ nanomaterials were successfully synthesized at different nitridation temperatures.
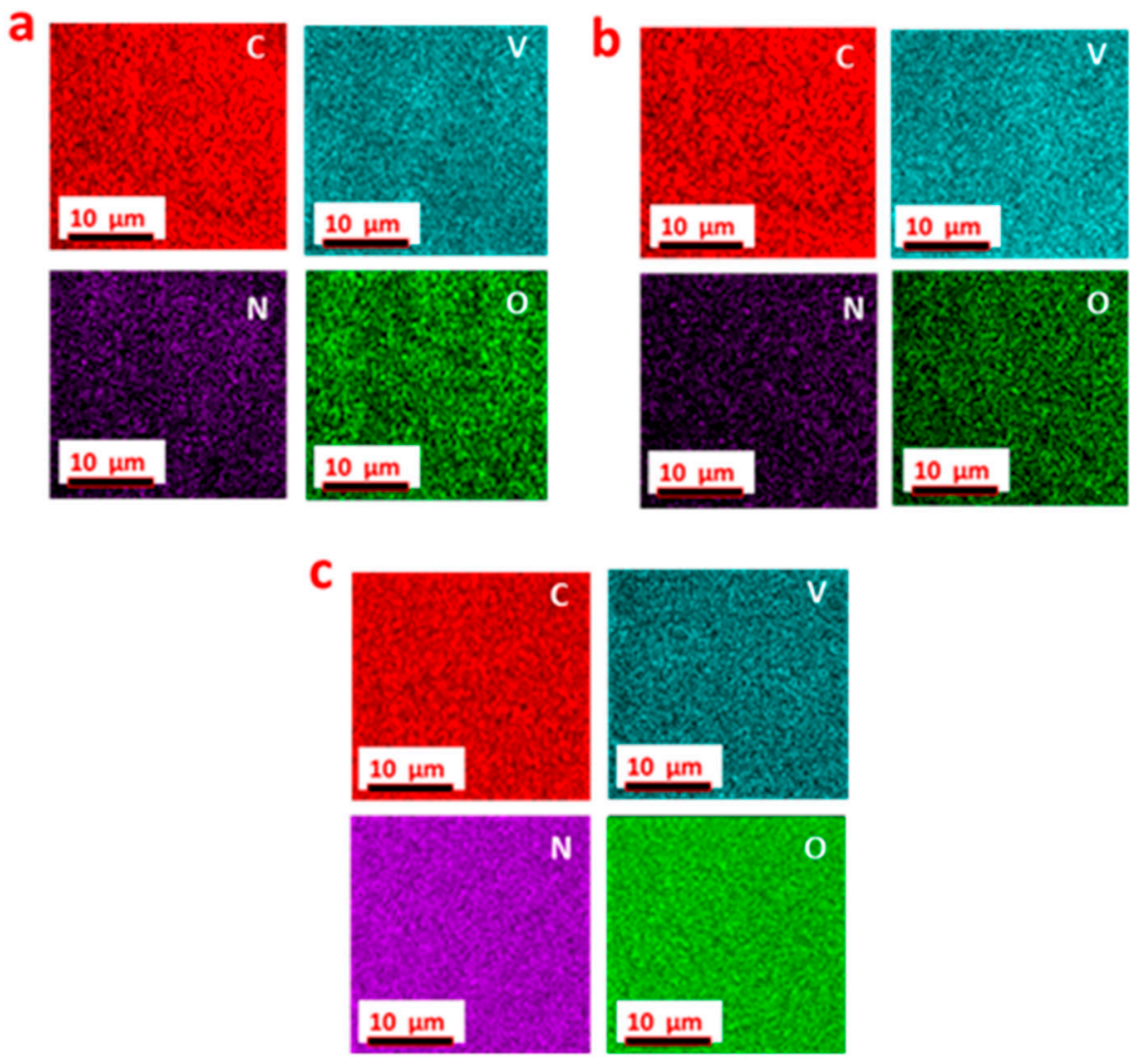

Figure 4. Distribution of individual elements in: (a) $\mathrm{C}-\mathrm{V}_{2} \mathrm{NO} @ 700{ }^{\circ} \mathrm{C}$, (b) $\mathrm{C}-\mathrm{V}_{2} \mathrm{NO} @ 800{ }^{\circ} \mathrm{C}$ and (c) $\mathrm{C}-\mathrm{V}_{2} \mathrm{NO} @ 900{ }^{\circ} \mathrm{C}$ materials.

Table 2 shows the presence of carbon, nitrogen, vanadium and oxygen with their respective content. At $800{ }^{\circ} \mathrm{C}$, the materials displayed higher $\mathrm{C}$ and $\mathrm{N}$ content as compared to the others. The oxygen content was found to decrease with the nitridation temperature. The different atomic composition values confirmed the dependence of the nitridation temperature on the element content which can affect the electrochemical performance of the materials.

Table 2. Carbon, vanadium, nitrogen and oxygen contents in the $\mathrm{C}-\mathrm{V}_{2} \mathrm{NO}$ materials.

\begin{tabular}{cccccc}
\hline Material & $\mathbf{C}(\mathbf{W t} \%)$ & $\mathbf{V}(\mathbf{W t} \%)$ & $\mathbf{N}(\mathbf{W t} \%)$ & $\mathbf{O}(\mathbf{W t} \%)$ & Total \\
\hline $\mathrm{C}-\mathrm{V}_{2} \mathrm{NO} @ 700{ }^{\circ} \mathrm{C}$ & 62 & 17 & 5 & 16 & 100 \\
$\mathrm{C}-\mathrm{V}_{2} \mathrm{NO} @ 800^{\circ} \mathrm{C}$ & 66 & 11 & 9 & 14 & 100 \\
$\mathrm{C}-\mathrm{V}_{2} \mathrm{NO} @ 900^{\circ} \mathrm{C}$ & 64 & 18 & 7 & 11 & 100 \\
\hline
\end{tabular}

A more detailed analysis of the $\mathrm{C}-\mathrm{V}_{2} \mathrm{NO}$ nanostructure was obtained from transmission electron microscopy (TEM) studies. Figure 5 shows the TEM images of all the nanomaterials which revealed that the materials could be viewed as interconnected porous web-like structures. Based 
on the XRD, Raman and SEM analyses, the selected area electron diffraction (SAED) pattern of the $\mathrm{C}-\mathrm{V}_{2} \mathrm{NO} @ 800{ }^{\circ} \mathrm{C}$ nanomaterials was evaluated and presented in Figure S2 (Supporting information). It shows the electron diffraction planes at (111), (200), and (220) which corresponds to the vanadium oxynitride-carbon structure.
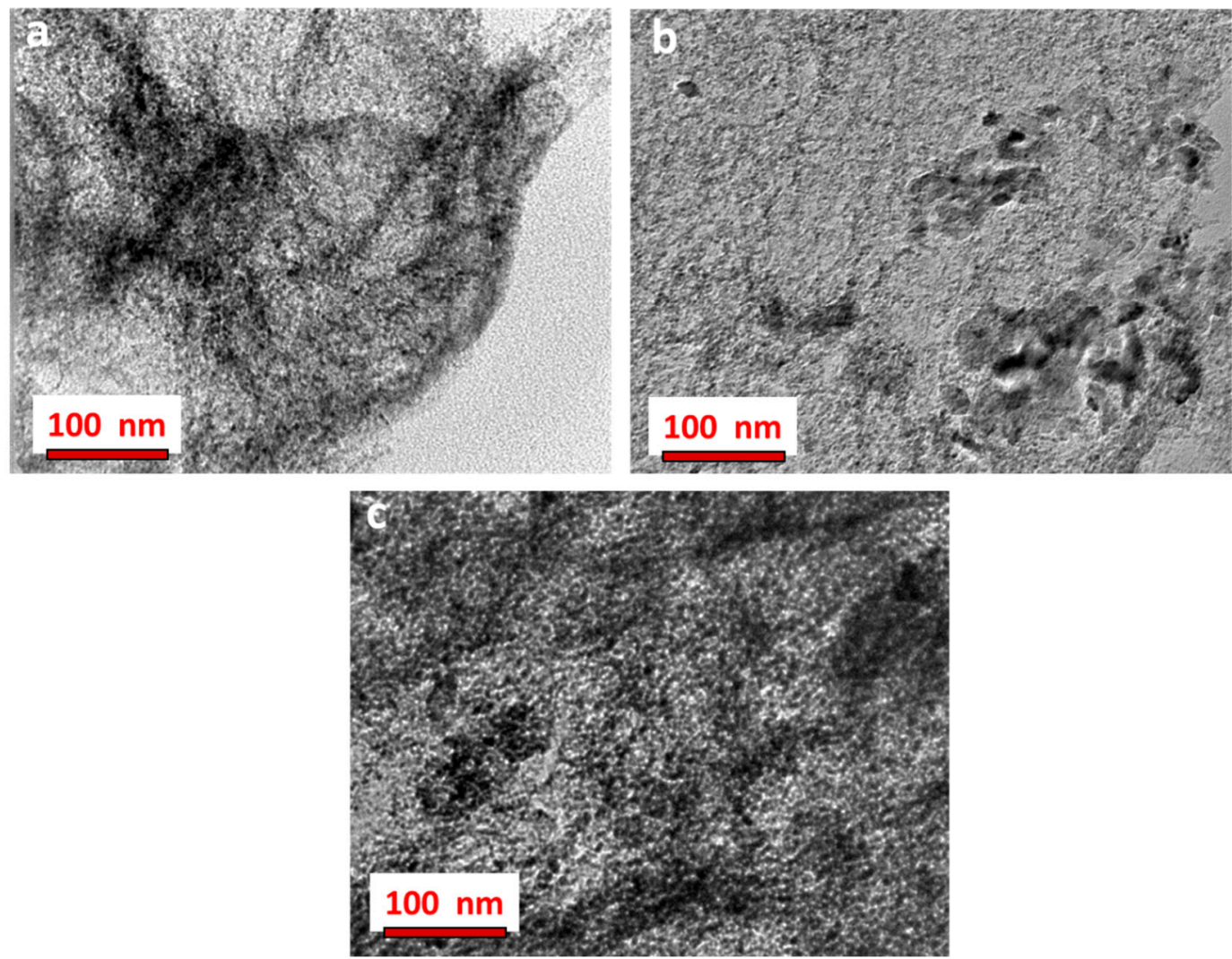

Figure 5. Transmission electron microscope (TEM) images of the synthesized $\mathrm{C}-\mathrm{V}_{2} \mathrm{NO}$ nanomaterials: (a) $\mathrm{C}-\mathrm{V}_{2} \mathrm{NO} @ 700{ }^{\circ} \mathrm{C}$, (b) $\mathrm{C}-\mathrm{V}_{2} \mathrm{NO} @ 800{ }^{\circ} \mathrm{C}$ and (c) $\mathrm{C}-\mathrm{V}_{2} \mathrm{NO} @ 900{ }^{\circ} \mathrm{C}$.

To investigate the porosity properties of the nanomaterials, $\mathrm{N}_{2}$ adsorption-desorption measurement was carried out on $\mathrm{C}-\mathrm{V}_{2} \mathrm{NO}$ nanomaterials at 700, 800 and $900{ }^{\circ} \mathrm{C}$, as shown in Figure 6. The $\mathrm{N}_{2}$ isotherm of the $\mathrm{C}-\mathrm{V}_{2} \mathrm{NO}$ nanomaterials in Figure 6a depicted a type IV adsorption-desorption isotherm with a H3 hysteresis behaviour associated with plate-like particles giving rise to slit-shaped pores [37]. The specific surface areas (SSAs) of the different carbon-vanadium oxynitride nanomaterials obtained were $91.6 \pm 0.22 \mathrm{~m}^{2} \mathrm{~g}^{-1}, 121.6 \pm 0.83 \mathrm{~m}^{2} \mathrm{~g}^{-1}$ and $113 \pm 0.74 \mathrm{~m}^{2} \mathrm{~g}^{-1}$ at 700,800 and $900{ }^{\circ} \mathrm{C}$, respectively. The synthesis of these mesoporous interconnected web-like structures with controlled growth temperature yielded higher value of the specific surface area as compared to those reported in the literature namely, $28.8 \mathrm{~m}^{2} \mathrm{~g}^{-1}$ for $\mathrm{VO}_{x} \mathrm{~N}_{y}, 40.8 \mathrm{~m}^{2} \mathrm{~g}^{-1}$ for $\mathrm{VO}_{x} \mathrm{~N}_{y}-\mathrm{C}$ [22] and $60 \mathrm{~m}^{2} \mathrm{~g}^{-1}$ for $\mathrm{TiO}_{x} \mathrm{~N}_{y}$ [38], respectively.

Figure $6 \mathrm{~b}$ shows the pore-size distribution with a pore diameter ranging from -2 to $8 \mathrm{~nm}$ which signifies the presence of a predominantly mesoporous $\mathrm{C}-\mathrm{V}_{2} \mathrm{NO}$ material. It shows clearly that the pore diameter of the $\mathrm{C}-\mathrm{V}_{2} \mathrm{NO}$ nanomaterial decrease with increasing nitridation temperature. The $\mathrm{C}-\mathrm{V}_{2} \mathrm{NO} @ 700{ }^{\circ} \mathrm{C}$ shows a broad pore size distribution whereas a narrow pore size distribution was observed for the $\mathrm{C}-\mathrm{V}_{2} \mathrm{NO}$ nanomaterials at 800 and $900{ }^{\circ} \mathrm{C}$. As seen in Figure $6 \mathrm{a}, \mathrm{b}$, the $\mathrm{C}-\mathrm{V}_{2} \mathrm{NO} @ 800{ }^{\circ} \mathrm{C}$ exhibited a higher specific surface area and a higher pore volume than the $\mathrm{C}-\mathrm{V}_{2} \mathrm{NO} @ 700{ }^{\circ} \mathrm{C}$ and $\mathrm{C}-\mathrm{V}_{2} \mathrm{NO} @ 900{ }^{\circ} \mathrm{C}$ which could be due to the highest ratio of disordered carbon relative to the graphitic carbon with a small pore diameter of $2 \mathrm{~nm}$. The pore diameter value of the $\mathrm{C}-\mathrm{V}_{2} \mathrm{NO} @ 800{ }^{\circ} \mathrm{C}(2 \mathrm{~nm})$ is smaller than those reported for most reports on mesoporous oxynitride-based materials such as mesoporous bimetallic molybdenum tungsten oxynitride (4 nm) [39], zirconium doped perovskite oxynitride $\mathrm{LaTaON}_{2}(20 \mathrm{~nm})$ [40], titanium oxynitride were grafted onto the surfaces of mesoporous 
silica $(2.18 \mathrm{~nm})$ [41]. This mesoporous structure of the $\mathrm{C}-\mathrm{V}_{2} \mathrm{NO} @ 800{ }^{\circ} \mathrm{C}$ could greatly increase the mass transport of electrolytes ions within the electrodes for fast redox reactions and thus further enhance the electrochemical performance.
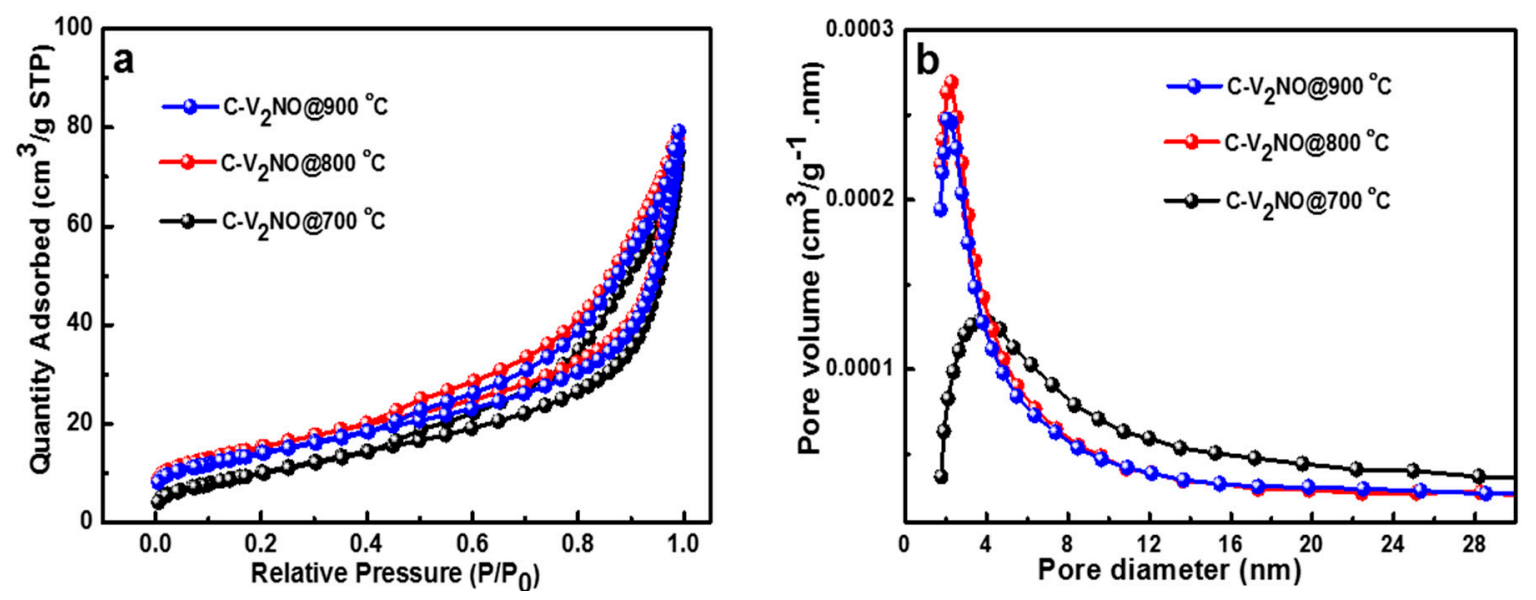

Figure 6. (a) $\mathrm{N}_{2}$ absorption/desorption isotherms and (b) pore size distribution of $\mathrm{C}-\mathrm{V}_{2} \mathrm{NO}$ at $700-900{ }^{\circ} \mathrm{C}$ nitridation temperature.

The formation of mesoporous carbon-vanadium oxynitride can be postulated to result from the reaction of vanadium metavanadate and melamine at higher temperatures. Typically, at high temperatures $\left(>220^{\circ} \mathrm{C}\right)$, the melamine decomposes to give $-\mathrm{CH}_{2},-\mathrm{C}-\mathrm{N}$ and nitrogen groups which form the matrix ring ( $\mathrm{N}-\mathrm{C}$ matrix) at higher temperatures [42] and the $\mathrm{NH}_{4} \mathrm{VO}_{3}$ decomposes at ( $>300{ }^{\circ} \mathrm{C}$ ) to yield vanadium oxides, $\mathrm{NH}_{3}$ gas and $\mathrm{H}_{2} \mathrm{O}$ [43,44]. The $\mathrm{NH}_{3}$ gas can further reduce the vanadium oxides in the presence of $-\mathrm{CH}_{2}$ and $\mathrm{N}-\mathrm{C}$ matrix from melamine decomposition leading to the formation of vanadium oxynitride material at higher temperatures $\left(500-1500^{\circ} \mathrm{C}\right)$ [45]. The presence of the metal oxide and $\mathrm{N}-\mathrm{C}$, as well as the $\mathrm{NH}_{3}$, favoured the formation of the carbon-vanadium oxynitride at high nitridation temperatures.

At $700{ }^{\circ} \mathrm{C}$, small nanoparticles of $\mathrm{C}-\mathrm{V}_{2} \mathrm{NO}$ were formed and connected in a web network with a moderate degree of graphitized carbon.

When the temperature was further increased to $800^{\circ} \mathrm{C}$, the particles are strongly interconnected to form a more mesoporous network (higher surface area) that can favour a better interaction of the $\mathrm{C}-\mathrm{V}_{2} \mathrm{NO}$ surface with the electrolyte. Consequently, the carbon network became more defective resulting in a lower degree of graphitization. At $900{ }^{\circ} \mathrm{C}$, however, the highly mesoporous network was disintegrated resulting in a decreased specific surface area and a moderately graphitized carbon network. Thus, nitridation temperature influenced the morphology, structure and surface area of the $\mathrm{C}-\mathrm{V}_{2} \mathrm{NO}$.

For all materials analysed, $\mathrm{C}-\mathrm{V}_{2} \mathrm{NO}$ prepared at $800{ }^{\circ} \mathrm{C}$ portrayed good crystallinity, a higher ratio of disorder with a well-interconnected porous structure. More specifically, it exhibited a high specific surface area and yielded an efficient nanometer-sized pores $(2 \mathrm{~nm})$ and therefore, presented an optimal nitridation process that could be beneficial for enhanced electrochemical performance. Thus, the XPS analysis of the $\mathrm{C}-\mathrm{V}_{2} \mathrm{NO} @ 800{ }^{\circ} \mathrm{C}$ was performed to determine the active species introduced into the material. Figure S3 (supporting information) shows the $\mathrm{C}, \mathrm{V}, \mathrm{O}$ and $\mathrm{N}$ peaks deconvoluted in high resolution into $\mathrm{C}_{1 \mathrm{~s}} \mathrm{~V}_{2 \mathrm{p}}, \mathrm{O}_{1 \mathrm{~s}}$ and $\mathrm{N}_{1 \mathrm{~s}}$ which confirms the configurations of carbon, nitrogen, oxygen and all the different vanadium ions $\left(\mathrm{V}^{2+}, \mathrm{V}^{3+}, \mathrm{V}^{4+}\right.$ and $\left.\mathrm{V}^{5+}\right)[10,25,46-56]$.

\section{Electrochemical Performance}

The electrochemical measurements of all the electrode materials were originally performed in a half-cell (three electrode) configuration using $6 \mathrm{M} \mathrm{KOH}$ aqueous electrolyte as seen in Figure 7. For comparison purposes, the electrochemical data of the nickel foam $(\mathrm{NiF})$ as an electrode is given in the 
supplementary information (Figure S4). Figure 7a,b shows the cyclic voltammogram (CV) plots of the different $\mathrm{C}-\mathrm{V}_{2} \mathrm{NO}$ nanomaterials in both positive $(0$ to $0.40 \mathrm{~V})$ and negative $(-1.20$ to $0 \mathrm{~V})$ potential window ranges at a $50 \mathrm{mV} \mathrm{s}^{-1}$ scan rate. As observed in these figures, the $\mathrm{CV}$ plots of $\mathrm{C}-\mathrm{V}_{2} \mathrm{NO} @ 800{ }^{\circ} \mathrm{C}$ exhibits a higher current response compared to the other $\mathrm{C}-\mathrm{V}_{2} \mathrm{NO}$ samples prepared at 700 and $900{ }^{\circ} \mathrm{C}$ in both operating potential ranges. All the CV curves of the electrodes present Faradaic behavior in the positive potential window and pseudocapacitive behavior in the negative potential window. As seen in Figure 7a, the CV curves of the nanomaterials show anodic and cathodic peaks shift. This kind of behaviour is normal for carbon-based materials measured in the positive potential widow using $\mathrm{KOH}$ electrolyte. The shift in the anodic peak observed from these three samples with 700 and $900{ }^{\circ} \mathrm{C}$ being different to that of $800{ }^{\circ} \mathrm{C}$ is due to carbon content and the amount of amorphous carbon that are close to each other for other temperatures as compared to $800^{\circ} \mathrm{C}$. Figure $7 \mathrm{c}$ shows clearly that the $\mathrm{C}-\mathrm{V}_{2} \mathrm{NO} @ 800^{\circ} \mathrm{C}$ electrode presents the highest specific capacity value as a function of the nitridation temperature in the positive and in the negative potential windows.

Figure 7d displays the Nyquist plot with the inset showing equivalent series resistance (ESR) as a function of nitridation temperature for different $\mathrm{C}-\mathrm{V}_{2} \mathrm{NO}$ electrodes. More specifically, the $\mathrm{C}-\mathrm{V}_{2} \mathrm{NO} @ 800{ }^{\circ} \mathrm{C}$ electrode shows smallest ESR, a shorter diffusion length and is closer to the vertical line ( $Z^{\prime \prime}$-axis) than the other electrode materials. This low ESR value for $800{ }^{\circ} \mathrm{C}$ can be related to a good ion diffusion at the electrode-electrolyte interface and fast charge transport between the electrode and the current collector which are greatly influenced by the surface chemistry of the $\mathrm{C}-\mathrm{V}_{2} \mathrm{NO} @ 800{ }^{\circ} \mathrm{C}$ electrode.

As can clearly be seen in the three-electrode configuration, the electrochemical measurements of the $\mathrm{C}-\mathrm{V}_{2} \mathrm{NO} @ 800{ }^{\circ} \mathrm{C}$ depicted a superior electrochemical response based on the result in Figure 7 . It also shows good stability in terms of capacity retention (94\%) over 5000 cycles at $10 \mathrm{~A} \mathrm{~g}^{-1}$ as shown in the supplementary information (Figure S5). This is linked to the mesoporous web-like morphology of the $\mathrm{C}-\mathrm{V}_{2} \mathrm{NO} @ 800{ }^{\circ} \mathrm{C}$ coupled with the high SSA and a small pore diameter which provides an efficient contact between the surface of electroactive web-like and the $6 \mathrm{M} \mathrm{KOH}$ even at high rates to build up a good path for fast electron transport [25]. In addition, the high $\mathrm{I}_{\mathrm{D}} / \mathrm{I}_{\mathrm{G}}$ ratio of the $\mathrm{C}-\mathrm{V}_{2} \mathrm{NO} @ 800{ }^{\circ} \mathrm{C}$ yielded a good affinity for the $6 \mathrm{M} \mathrm{KOH}$ electrolyte ions due to the surface hydrophilicity and the good carbon surface wettability. From this result, the electrochemical measurements for a full-cell device is carried out using $\mathrm{C}-\mathrm{V}_{2} \mathrm{NO} @ 800{ }^{\circ} \mathrm{C}$ samples as both negative and positive electrode to produce a symmetric device.

Figure $8 \mathrm{a}, \mathrm{b}$ shows the $\mathrm{CV}$ plot of the $\mathrm{C}-\mathrm{V}_{2} \mathrm{NO} @ 800{ }^{\circ} \mathrm{C}$ electrode materials in both positive $(0$ to $0.4 \mathrm{~V})$ and negative $(-1.2$ to $0 \mathrm{~V})$ potential window ranges at different scan rates ranging from 5 to $100 \mathrm{mV} \mathrm{s}^{-1}$. The CV curve depicts a Faradaic electrode material in the positive potential window as seen in Figure 8a. This behaviour was confirmed by the presence of a pair of redox peaks at a scan rate of $50 \mathrm{mV} \mathrm{s}^{-1}$ which correspond to the anodic peak $(-0.12 \mathrm{~V})$ and cathodic peak $(-0.35 \mathrm{~V})$. Figure $8 \mathrm{~b}$ shows a pseudocapacitive behavior in the negative potential window with two redox peaks during the anodic $(-0.80,-0.38 \mathrm{~V})$ and the cathodic $(-0.87,-0.53 \mathrm{~V})$.

These Faradaic and pseudocapacitive processes in the positive and negative potential windows are due to the presence of the vanadium oxide in the material which indicates a reversible redox reaction [57]. Based on the literature, vanadium oxides may lead to a redox reaction, but it is a challenge to assign the peak to an individual oxide [58]. 

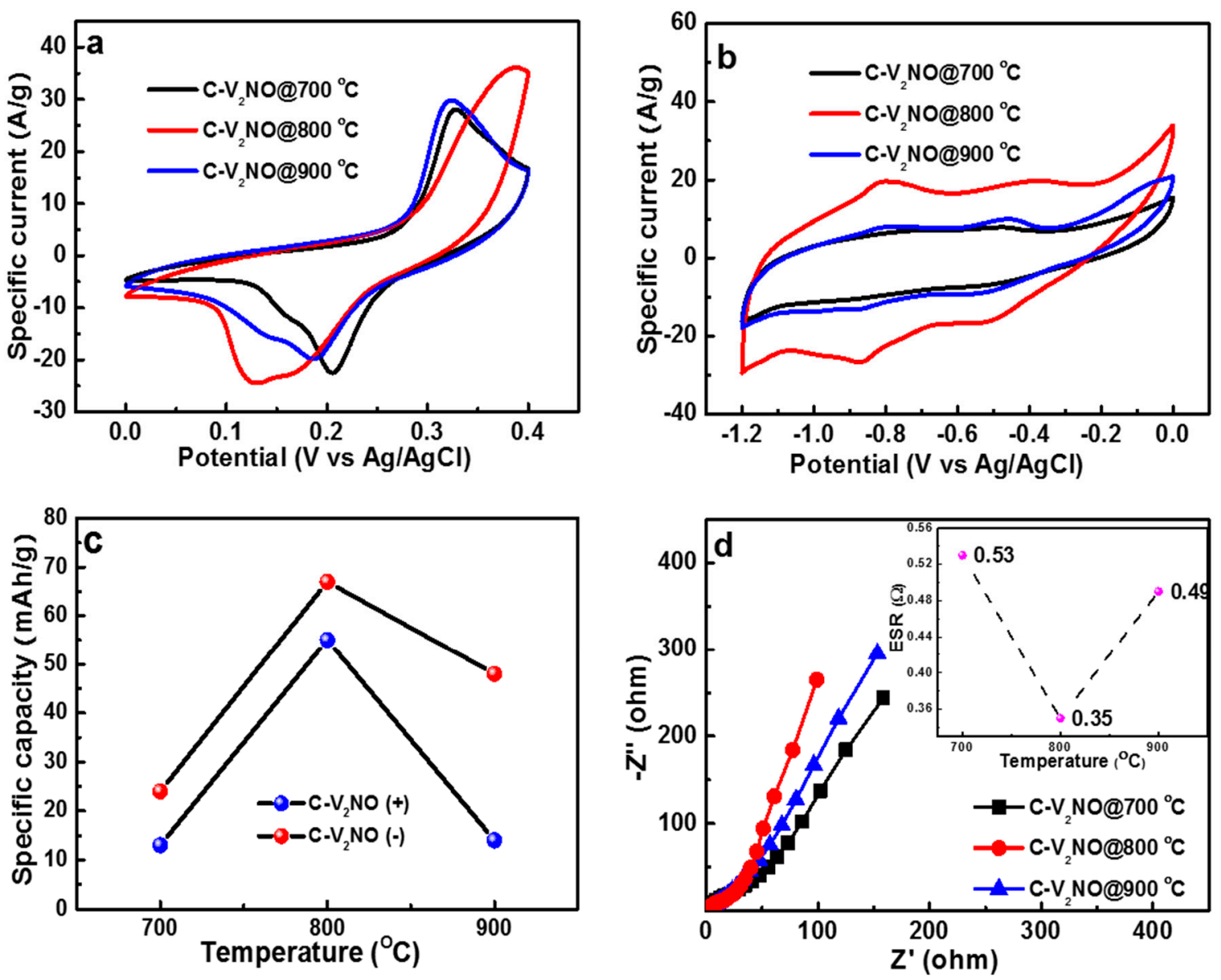

Figure 7. (a) The cyclic voltammetry $(\mathrm{CV})$ curve of the $\mathrm{C}-\mathrm{V}_{2} \mathrm{NO}$ electrodes in both positive (0 to $0.4 \mathrm{~V}),(\mathbf{b})$ negative $(-1.2$ to $0 \mathrm{~V})$ potential window ranges at $50 \mathrm{mV} \mathrm{s}^{-1}$, (c) the specific capacity of the $\mathrm{C}-\mathrm{V}_{2} \mathrm{NO}$ as positive and negative electrodes as a function of nitridation temperature at a specific current of $1 \mathrm{~A} \mathrm{~g}^{-1}$ and (d) the Nyquist plot (the inset is the equivalent series resistance (ESR) at different nitridation temperatures) for the $\mathrm{C}-\mathrm{V}_{2} \mathrm{NO}$ electrodes material.

Figure $8 \mathrm{c}$ displays the associated GCD plot at different specific current value. The existence of a Faradaic behaviour is depicted with the non-linear discharge profile in the potential window of 0 to $0.4 \mathrm{~V}$. Figure $8 \mathrm{~d}$ shows the GCD curves at different specific currents in the potential window of -1.2 to $0 \mathrm{~V}$. It confirmed the existence of a pseudocapacitive behavior as shown in Figure $8 \mathrm{~b}$. Figure $8 \mathrm{e}$ shows the specific capacity of the $\mathrm{C}-\mathrm{V}_{2} \mathrm{NO} @ 800^{\circ} \mathrm{C}$ calculated in the positive and the negative potential window at different specific currents ranging from 1 to $10 \mathrm{~A} \mathrm{~g}^{-1}$. The specific capacities of the $\mathrm{C}-\mathrm{V}_{2} \mathrm{NO} @ 800{ }^{\circ} \mathrm{C}$ were found to be 55 and $67 \mathrm{~mA} \mathrm{~h} \mathrm{~g}^{-1}$ in the positive and in the negative potential window, respectively, at a specific current of $1 \mathrm{~A} \mathrm{~g}^{-1}$.

To further demonstrate the electrochemical performance of the $\mathrm{C}-\mathrm{V}_{2} \mathrm{NO} @ 800{ }^{\circ} \mathrm{C}$ electrode extensively, a symmetric cell was fabricated using the materials prepared at $800{ }^{\circ} \mathrm{C}$ as both positive and negative electrodes $\left(\mathrm{C}-\mathrm{V}_{2} \mathrm{NO} / / \mathrm{C}-\mathrm{V}_{2} \mathrm{NO}\right)$ in the same electrolyte $(6 \mathrm{M} \mathrm{KOH})$. Figure 9 a shows the $\mathrm{CV}$ profiles of the $\mathrm{C}-\mathrm{V}_{2} \mathrm{NO} @ 800{ }^{\circ} \mathrm{C}$ measured in stable working potential windows of -1.2 to $0 \mathrm{~V}$ and 0 to $0.4 \mathrm{~V}$, respectively, at a scan rate of $50 \mathrm{mV} \mathrm{s}^{-1}$, and an estimation of the working potential window of $1.6 \mathrm{~V}$ could be expected from the symmetric device.

Figure $9 \mathrm{~b}$ presents $\mathrm{CV}$ plots at different voltages such as $1.6,1.7$ and $1.8 \mathrm{~V}$ using a scan rate of $30 \mathrm{mV} \mathrm{s}^{-1}$. The cyclic voltammogram curve at $1.8 \mathrm{~V}$ shows the highest current response and good contribution of the two behaviours of $\mathrm{C}-\mathrm{V}_{2} \mathrm{NO} @ 800^{\circ} \mathrm{C}$ in both positive and negative voltages compared to other (1.6 and 1.7 V). Moreover, the current leap at large voltage of $1.8 \mathrm{~V}$ was not observed, implying 
the stability of the symmetric device in this voltage (Figure $9 \mathrm{~b}$ ). Therefore, it can be concluded that the maximum stable working potential of the $\mathrm{C}-\mathrm{V}_{2} \mathrm{NO} / / \mathrm{C}-\mathrm{V}_{2} \mathrm{NO}$ symmetric device is $1.8 \mathrm{~V}$.
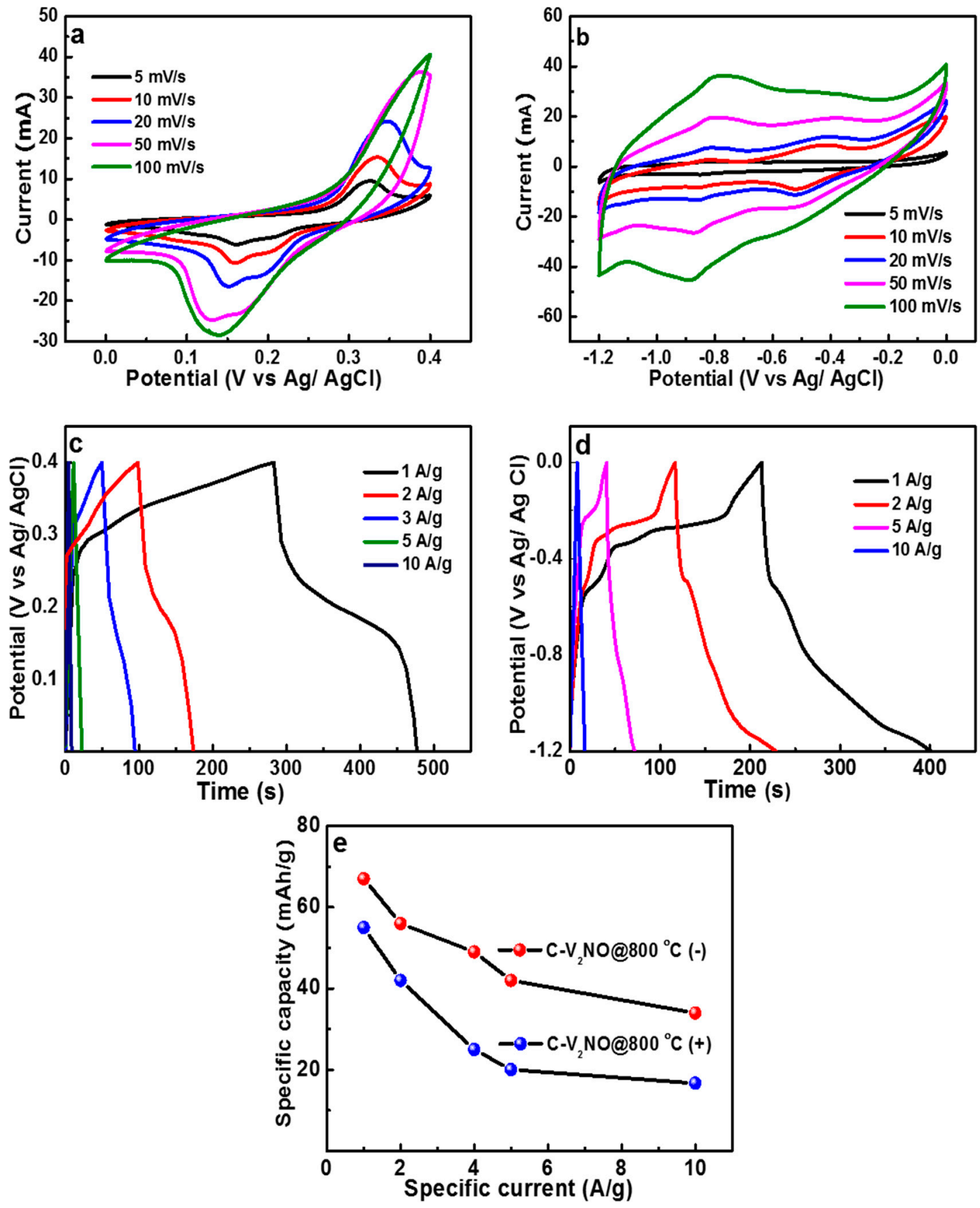

Figure 8. (a) CV plots at different scan rates, (b) galvanostatic charge-discharge (GCD) plots at different specific currents in a positive ( 0 to $0.4 \mathrm{~V}$ ) potential window, (c) CV curves at different scan rates, (d) GCD curves at different specific currents in a negative ( -1.2 to $0 \mathrm{~V}$ ) potential window of and (e) specific capacity of both positive and negative electrodes against specific current. 

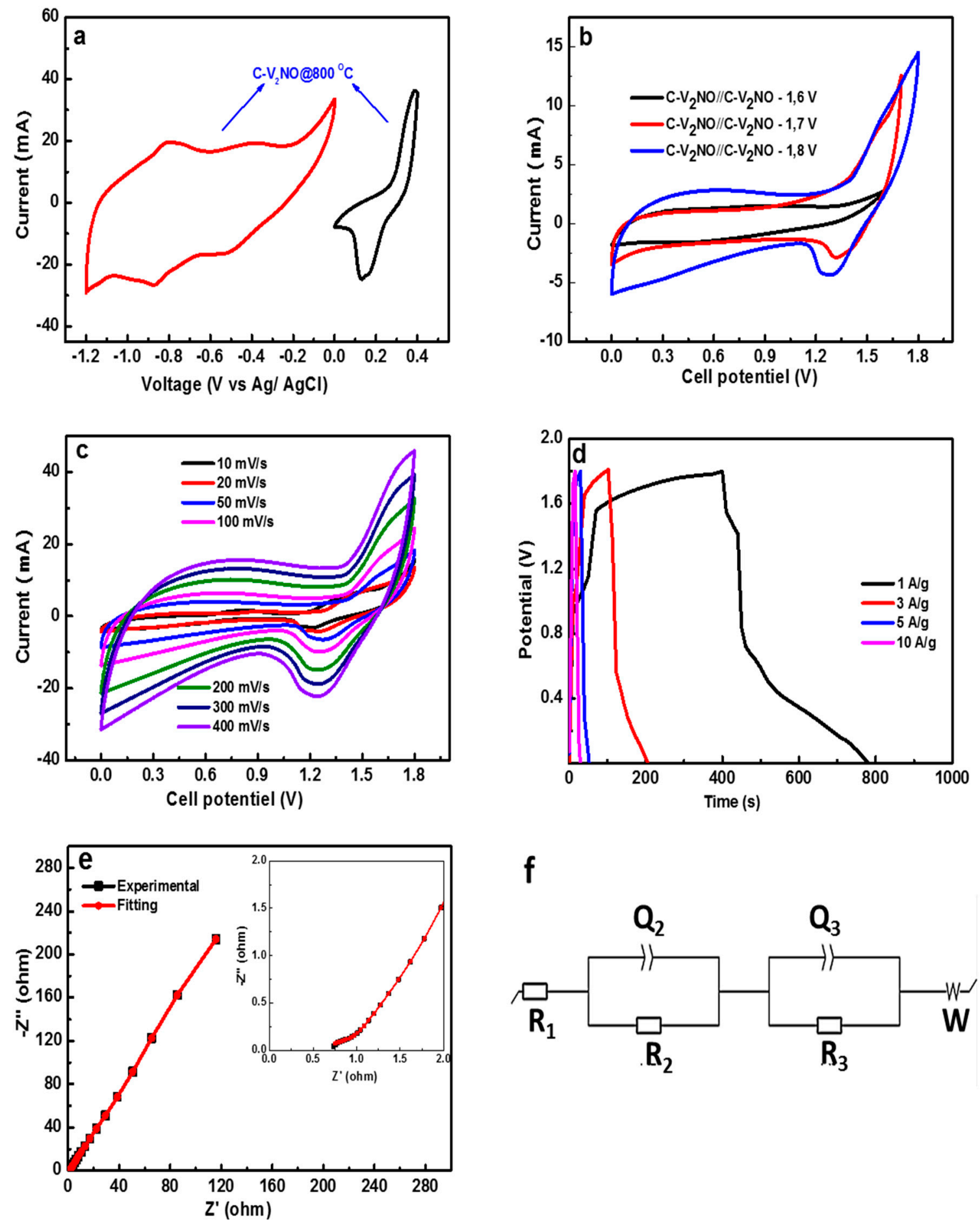

f

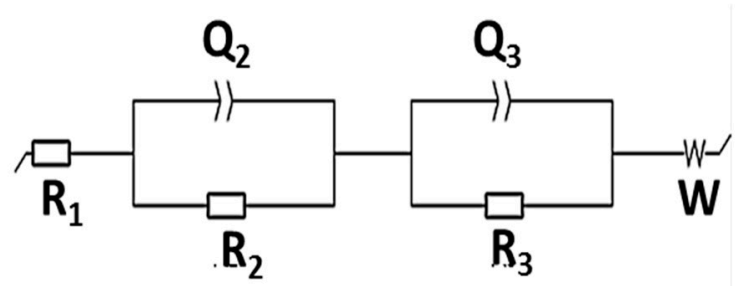

Figure 9. (a) Combined $\mathrm{CV}$ plots from the negative and positive potential window of the $\mathrm{C}-\mathrm{V}_{2} \mathrm{NO} @ 800{ }^{\circ} \mathrm{C}$ electrode at $50 \mathrm{mV} \mathrm{s}^{-1},(\mathbf{b}) \mathrm{CV}$ at $1.6,1.7$ and $1.8 \mathrm{~V}$ at $30 \mathrm{mV} \mathrm{s}^{-1}$, (c) $\mathrm{CV}$ plot at different scan rates for cell potential of $1.8 \mathrm{~V},(\mathbf{d}) \mathrm{GCD}$ plot of the device at different specific currents, (e) the fitted Nyquist plot with the electrochemical impedance spectroscopic (EIS) plot and (f) equivalent circuit of the $\mathrm{C}-\mathrm{V}_{2} \mathrm{NO} / / \mathrm{C}-\mathrm{V}_{2} \mathrm{NO}$ symmetric device.

Figure $9 \mathrm{c}$ shows the $\mathrm{CV}$ curves of the $\mathrm{C}-\mathrm{V}_{2} \mathrm{NO} / / \mathrm{C}-\mathrm{V}_{2} \mathrm{NO}$ symmetric supercapacitor at different scan rates ranging from $5-400 \mathrm{mV} \mathrm{s}^{-1}$ in an operating voltage of $1.8 \mathrm{~V}$. The $\mathrm{CV}$ curves indicate a combination and the contribution of pseudocapacitive and Faradaic charge storage mechanisms. As observed, the $\mathrm{CV}$ curves present the same behavior from 5 to $400 \mathrm{mV} \mathrm{s}^{-1}$ scan rates, indicating rapid redox reactions 
at high scan rates. The specific current increases proportionally as a function of increased scan rate indicating the good rate capability of the symmetric device. Figure $9 \mathrm{~d}$ shows the GCD profiles of $\mathrm{C}-\mathrm{V}_{2} \mathrm{NO} / / \mathrm{C}-\mathrm{V}_{2} \mathrm{NO}$ symmetric device at different specific currents of 1-10 $\mathrm{A} \mathrm{g}^{-1}$ with a large voltage of 0-1.8 V. The GCD curves exhibited faradaic behavior for the symmetric device in agreement with CV curves from Figure 9b. Figure 9e illustrates the Nyquist plot and the fitting data (seen in red solid-line) of the symmetric device. The ESR value obtained experimentally is $0.74 \Omega$ which is close to the values recorded from the fitting data suggesting an excellent fit with the experimental Nyquist plot. Figure $9 f$ shows the equivalent circuit adopted to fit the electrochemical impedance spectroscopic (EIS) using a software ZFIT/EC-Lab version 10.40. In the Figure, $R_{1}$ is the equivalent series (solution) resistance, and $R_{2}$ and $Q_{2}$ represent the rate of resistance and the electrochemical Faradaic activity, respectively. The equivalent series resistance is associated with the ohmic resistance of the electrode. In the high frequency, the $R_{1}$ in series with the constant phase element $Q_{2}$ and is placed in parallel with the $R_{2}$. In the low-frequency, a close vertical line has been shown which is associated with an ideal supercapacitor giving a mass capacitance, $Q_{3}$. The Nyquist plot of the symmetric device presents a slight deviation from the $Y$-axis which is mainly associated with the leakage resistance $R_{3}$ arising from the Faradaic charge transfer process. The $Q_{3}$ is in parallel to the $R_{3}$ which is in series with the Warburg impedance characteristic element $(\mathrm{W})[59,60]$.

Figure 10a presents the profile of the specific capacity as a function of specific current. A specific capacity value of $58 \mathrm{~mA} \mathrm{~h} \mathrm{~g}^{-1}$ of the symmetric device was recorded at $1 \mathrm{~A} \mathrm{~g}^{-1}$. This was retained at $18.7 \mathrm{~mA} \mathrm{~h} \mathrm{~g}^{-1}$ for a specific current of $10 \mathrm{~A} \mathrm{~g}^{-1}$. Figure $10 \mathrm{~b}$ exhibits the Ragone plot which describes the power density against energy density for the symmetric capacitor using different specific currents range of 1-10 $\mathrm{A} \mathrm{g}^{-1}$. The specific energy of the $\mathrm{C}-\mathrm{V}_{2} \mathrm{NO} / / \mathrm{C}-\mathrm{V}_{2} \mathrm{NO}$ was $38 \mathrm{~W} \mathrm{~h} \mathrm{~kg}^{-1}$ with a related specific power of $764 \mathrm{~W} \mathrm{~kg}^{-1}$ at a specific current of $1 \mathrm{~A} \mathrm{~g}^{-1}$. At $10 \mathrm{~A} \mathrm{~g}^{-1}$ the specific energy was $12.4 \mathrm{~W} \mathrm{~h} \mathrm{~kg}-1$ with an equivalent specific power of $6.6 \mathrm{~kW} \mathrm{~kg}^{-1}$. These values are superior to those reported for other symmetric oxy/nitride-based materials as shown in Figure 10b. For instance, Wang et al. [61] successfully synthesized $\mathrm{MnO}_{2} / \mathrm{TiO}_{1-x} \mathrm{~N}_{x}$ nanomaterials by depositing $\mathrm{MnO}_{2}$ on $\mathrm{TiO}_{0.54} \mathrm{~N}_{0.46}$ nanotubes. The $\mathrm{TiO}_{1-x} \mathrm{~N}_{x}$ was prepared by using a CVD (chemical vapor deposition) system in an ammonia atmosphere at high temperature. The symmetric configuration delivered an specific energy value of $9.8 \mathrm{~W} \mathrm{~h} \mathrm{~kg}^{-1}$ and a specific power value of $620 \mathrm{~W} \mathrm{~kg}^{-1}$ at $100 \mathrm{~A} \mathrm{~g}^{-1}$ using $1 \mathrm{M} \mathrm{KCl}$ electrolyte [61]. Recently, Yan et al. [62] prepared a carbon anchored titanium carbonitride materials using a semi-solid-state carbonitridation route. The electrochemical performance of the symmetric cell can store a specific energy of $8.6 \mathrm{~W} \mathrm{~h} \mathrm{~kg}^{-1}$ and deliver a specific power of $160.5 \mathrm{~W} \mathrm{~kg}^{-1}$ at a specific current of $1 \mathrm{~A} \mathrm{~g}^{-1}$ in $\mathrm{PVA} / \mathrm{H}_{2} \mathrm{SO}_{4}$ electrolyte [62].

In this work, the high specific energy and power value of the $\mathrm{C}-\mathrm{V}_{2} \mathrm{NO} / / \mathrm{C}-\mathrm{V}_{2} \mathrm{NO}$ cell observed can be attributed to the excellent electrochemical performance of the $\mathrm{C}-\mathrm{V}_{2} \mathrm{NO} @ 800{ }^{\circ} \mathrm{C}$ working in a stable voltage of $1.8 \mathrm{~V}$.

To evaluate the device stability of the $\mathrm{C}-\mathrm{V}_{2} \mathrm{NO} / / \mathrm{C}-\mathrm{V}_{2} \mathrm{NO}$, constant cycling (charging-discharging) and floating time (voltage holding) tests were performed to study device degradation with varying parameters. Figure 10c shows the plot of capacity retention of the symmetric device as a function of cycle number at a high gravimetric current of $10 \mathrm{~A} \mathrm{~g}^{-1}$.

The cycling stability presented a good capacity retention of $84.7 \%$ up to 10,000 cycles, suggesting a good electrochemical stability of the symmetric cell. The floating test was evaluated after 10,000 stability test at $10 \mathrm{~A} \mathrm{~g}^{-1}$ by monitoring the specific capacity after every $10 \mathrm{~h}$ interval for up to $100 \mathrm{~h}$ and the result is shown in Figure 10d. The specific capacity value considerably increased after $50 \mathrm{~h}$ of voltage holding. This appreciable improvement can be seen clearly after calculating the specific energy for each voltage holding time as shown in Figure 10e. Interestingly, the specific energy value after $50 \mathrm{~h}$ improved from 23 to $27 \mathrm{~W} \mathrm{~h} \mathrm{~kg}^{-1}$ before reaching a plateau at a value of $32 \mathrm{~W} \mathrm{~h} \mathrm{~kg}^{-1}$, corresponding to an increase of $27 \%$ from the original value of $23 \mathrm{~W} \mathrm{~h} \mathrm{~kg}^{-1}$. This increase in specific capacity and specific energy can be associated to the increase in accessibility of the ions to initially inaccessible redox sites which could increase the wettability and a large diffusion of ions between the 
electrolyte/electrode during the long floating time $(100 \mathrm{~h})$ [63]. The cycling stability and the floating test of the device indicated that the symmetric device showed a good long-term stability without any significant degradation.
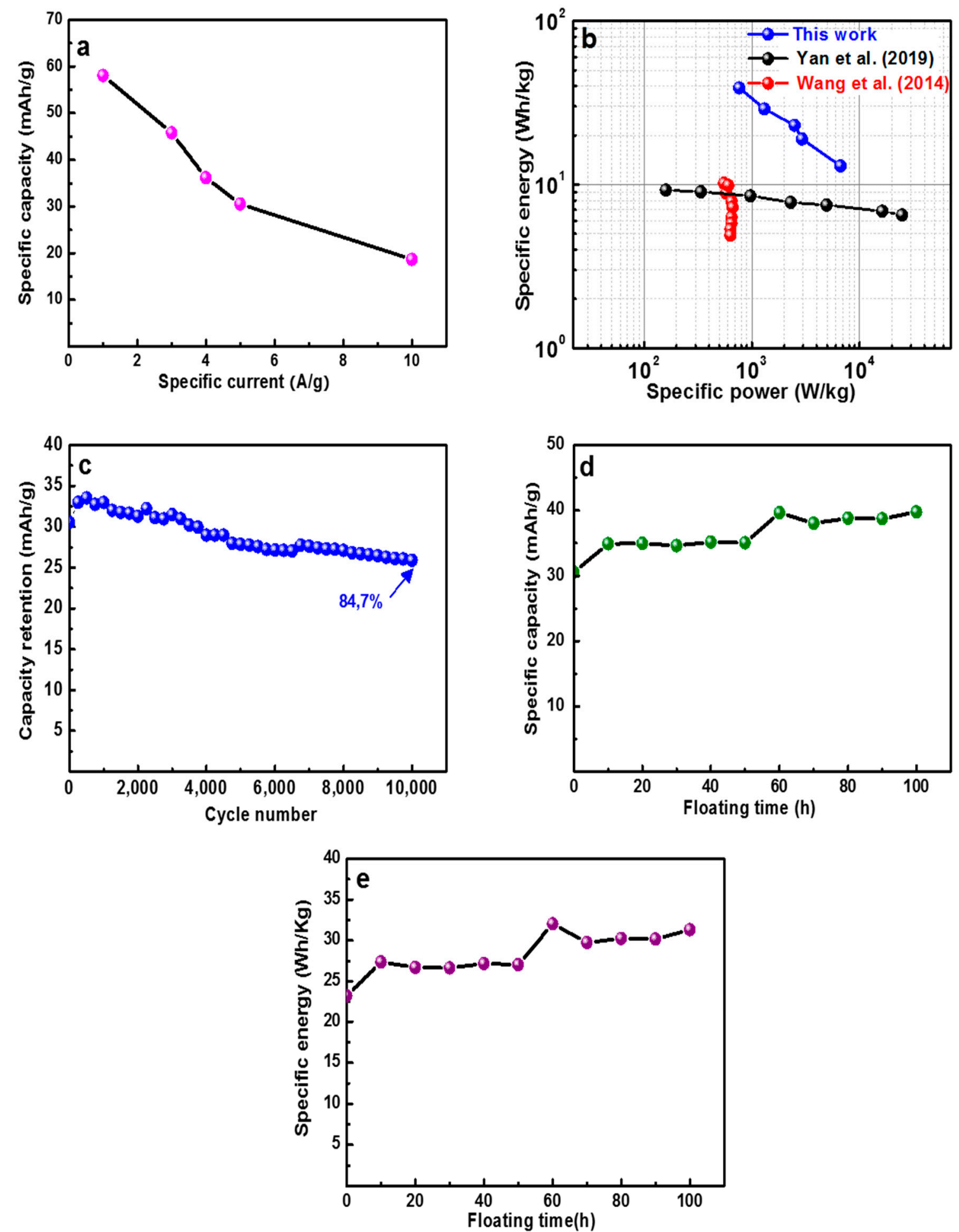

Figure 10. (a) Specific capacity of the $\mathrm{C}-\mathrm{V}_{2} \mathrm{NO} / / \mathrm{C}-\mathrm{V}_{2} \mathrm{NO}$ at different specific current in the full-cell configuration, (b) Ragone plot, (c) stability test for up to 10,000 cycles, (d) specific capacity and (e) energy density against a floating time of $100 \mathrm{~h}$ at $10 \mathrm{~A} \mathrm{~g}^{-1}$. 


\section{Conclusions}

In this study, a porous carbon-vanadium oxynitride $\left(\mathrm{C}-\mathrm{V}_{2} \mathrm{NO}\right)$ nanostructure was obtained at different nitridation temperatures of 700,800 and $900{ }^{\circ} \mathrm{C}$ using a thermal decomposition method. All the synthesized nanomaterials exhibited single phase $\mathrm{C}-\mathrm{V}_{2} \mathrm{NO}$ cubic structures. The BET analysis of the $\mathrm{C}-\mathrm{V}_{2} \mathrm{NO}$ nanomaterials showed a good specific surface area (SSA) (from 91.6 to $121.6 \mathrm{~m}^{2} \mathrm{~g}^{-1}$ ) with a pore diameter ranging from -2 to $8 \mathrm{~nm}$. The nitridation temperature played a crucial role in modulating the $\mathrm{C}-\mathrm{V}_{2} \mathrm{NO}$ crystallinity, surface area, and elemental composition. The $\mathrm{C}-\mathrm{V}_{2} \mathrm{NO} @ 700{ }^{\circ} \mathrm{C}$ nanostructure displayed a low surface area and a moderate degree of graphitization. The $\mathrm{C}-\mathrm{V}_{2} \mathrm{NO} @ 800{ }^{\circ} \mathrm{C}$ nanomaterials showed a higher ratio of disorder with a well interconnected cavities structure and a narrower pore size distribution. In contrast, $\mathrm{C}-\mathrm{V}_{2} \mathrm{NO} @ 900{ }^{\circ} \mathrm{C}$ gave a disintegrated network with a moderate degree of graphitization and a decrease in surface area compared to the $\mathrm{C}-\mathrm{V}_{2} \mathrm{NO} @ 800{ }^{\circ} \mathrm{C}$. Therefore, a nitridation temperature of $800{ }^{\circ} \mathrm{C}$ was found to be the optimal temperature for the generation of a suitable $\mathrm{C}-\mathrm{V}_{2} \mathrm{NO}$ nanostructure with the highest electrochemical performance in both the positive and negative potential windows. A symmetric capacitor was fabricated using $\mathrm{C}-\mathrm{V}_{2} \mathrm{NO} @ 800{ }^{\circ} \mathrm{C}$ revealing a specific energy value of $38 \mathrm{~W} \mathrm{~h} \mathrm{~kg}{ }^{-1}$ and a specific power value of $764 \mathrm{~W} \mathrm{~kg}^{-1}$ at $1 \mathrm{~A} \mathrm{~g}^{-1}$ in a voltage of $1.8 \mathrm{~V}$. The $\mathrm{C}-\mathrm{V}_{2} \mathrm{NO} / / \mathrm{C}-\mathrm{V}_{2} \mathrm{NO}$ exhibited a good cycling stability with $84.7 \%$ capacity retention up to 10,000 cycles at $10 \mathrm{~A} \mathrm{~g}^{-1}$. This excellent stability performance of the device was also confirmed via floating/aging test for up to $100 \mathrm{~h}$ showing a further improved device electrochemical performance.

Supplementary Materials: The following are available online at http://www.mdpi.com/2079-4991/9/12/1762/s1, Figure S1: The TEM images of the $\mathrm{C}-\mathrm{V}_{2} \mathrm{NO} @ 800{ }^{\circ} \mathrm{C}$ nanomaterials, Figure S2: The selected area electron diffraction (SAED) pattern of the $\mathrm{C}-\mathrm{V}_{2} \mathrm{NO} @ 800^{\circ} \mathrm{C}$ nanomaterials, Figure S3: (a) Wide scan XPS spectrum of the $\mathrm{C}-\mathrm{V}_{2} \mathrm{NO} @ 800{ }^{\circ} \mathrm{C}$ materials, indicating deconvoluted spectra of (b) $\mathrm{V}_{2 \mathrm{p}}$ binding energy region, (c) $\mathrm{C}_{1 \mathrm{~s}}$ binding energy region, (d) N1s binding energy region and (e) $\mathrm{O}_{1 \mathrm{~s}}$ binding energy regions, respectively, Figure S4: CV plot of the $\mathrm{Ni}$ foam and active material at a scan rate of $20 \mathrm{mV} \mathrm{s}^{-1}$, Figure S5: Coulombic efficiency and capacity retention as a function of cycle number at a specific current of $10 \mathrm{~A} \mathrm{~g}^{-1} \mathrm{C}-\mathrm{V}_{2} \mathrm{NO} @ 800{ }^{\circ} \mathrm{C}$.

Author Contributions: N.M.N., N.F.S., B.D.N., B.K.M. and N.M. conceived the idea and designed the work. N.M.N. performed all the experiments as well as the material and electrochemical characterization. J.K.D. and S.C.R. assisted with the XRD, Raman and XPS analysis. All authors contributed to the interpretation of results and discussion. N.M. and B.D.N. supervised the experiments and revised the paper.

Funding: This research was funded by the South African Research Chairs Initiative (SARChI) of the Department of Science and Technology and the National Research Foundation (NRF) of South Africa (Grant No. 61056). Any idea, finding, conclusion or recommendation expressed in this material is that of the author(s). The NRF does not accept any liability in this regard. N. M. Ndiaye thanks 'Organization for Women in Science for the Developing World (OWSD) and Swedish International Development Cooperation Agency (Sida), NRF through SARChI in Carbon Technology and Materials and the University of Pretoria for financial support.

Conflicts of Interest: The authors declare no conflicts of interest.

\section{References}

1. Surendran, S.; Shanmugapriya, S.; Shanmugam, S.; Vasylechko, L.; Kalai Selvan, R. Interweaved Nickel Phosphide Sponge as an Electrode for Flexible Supercapattery and Water Splitting Applications. ACS Appl. Energy Mater. 2018, 1, 78-92. [CrossRef]

2. Huang, P.; Lethien, C.; Pinaud, S.; Brousse, K.; Laloo, R.; Turq, V.; Respaud, M.; Demortiere, A.; Daffos, B.; Taberna, P.L.; et al. On-chip and freestanding elastic carbon films for micro-supercapacitors. Science 2016, 351, 691-695. [CrossRef] [PubMed]

3. Kang, Y.J.; Chung, H.; Han, C.-H.; Kim, W. All-solid-state flexible supercapacitors based on papers coated with carbon nanotubes and ionic-liquid-based gel electrolytes. Nanotechnology 2012, 23, 065401. [CrossRef] [PubMed]

4. $\mathrm{Su}, \mathrm{F}$; $\mathrm{Miao}, \mathrm{M}$. Asymmetric carbon nanotube-MnO2 two-ply yarn supercapacitors for wearable electronics. Nanotechnology 2014, 25, 135401. [CrossRef] [PubMed]

5. Deng, L.; Zhang, G.; Kang, L.; Lei, Z.; Liu, C.; Liu, Z.-H.H. Graphene/VO2 hybrid material for high performance electrochemical capacitor. Electrochim. Acta 2013, 112, 448-457. [CrossRef] 
6. Simon, P.; Gogotsi, Y. Materials for electrochemical capacitors. Nat. Mater. 2008, 7, 845-854. [CrossRef]

7. Yu, L.; Chen, G.Z. High energy supercapattery with an ionic liquid solution of $\mathrm{LiClO}_{4}$. Faraday Discuss. 2016, 190, 231-240. [CrossRef]

8. Yu, L.; Chen, G.Z. Redox electrode materials for supercapatteries. J. Power Sour. 2016, 326, 604-612. [CrossRef]

9. Zhi, M.; Xiang, C.; Li, J.; Li, M.; Wu, N. Nanostructured carbon-metal oxide composite electrodes for supercapacitors: a review. Nanoscale 2013, 5, 72-88. [CrossRef]

10. Silversmit, G.; Depla, D.; Poelman, H.; Marin, G.B.; De Gryse, R. Determination of the V2p XPS binding energies for different vanadium oxidation states (V5+ to V0+). J. Electron Spectrosc. Relat. Phenom. 2004, 135, 167-175. [CrossRef]

11. Cherusseri, J.; Sambath Kumar, K.; Choudhary, N.; Nagaiah, N.; Jung, Y.; Roy, T.; Thomas, J. Novel mesoporous electrode materials for symmetric, asymmetric and hybrid supercapacitors. Nanotechnology 2019, 30, 202001. [CrossRef] [PubMed]

12. Yu, J.; Gao, X.; Cui, Z.; Jiao, Y.; Zhang, Q.; Dong, H.; Yu, L.; Dong, L. Facile Synthesis of Binary Transition Metal Sulfide Tubes Derived from NiCo-MOF-74 for High-Performance Supercapacitors. Energy Technol. 2019, 7, 1900018. [CrossRef]

13. He, T.; Wang, Z.; Li, X.; Tan, Y.; Liu, Y.; Kong, L.; Kang, L.; Chen, C.; Ran, F. Intercalation structure of vanadium nitride nanoparticles growing on graphene surface toward high negative active material for supercapacitor utilization. J. Alloys Compd. 2019, 781, 1054-1058. [CrossRef]

14. Kumar, U.N.; Ghosh, S.; Thomas, T. Metal Oxynitrides as Promising Electrode Materials for Supercapacitor Applications. ChemElectroChem 2019, 6, 1255-1272. [CrossRef]

15. Zheng, S.; Gao, L. Nanosized Titanium Oxynitride and Molybdenum Oxynitride Particles Assembled in Mesoporous Silica MCM-41. Mater. Sci. Forum 2006, 510-511, 138-141. [CrossRef]

16. Zhao, Y.M.; Hu, W.B.; Xia, Y.D.; Smith, E.F.; Zhu, Y.Q.; Dunnill, C.W.; Gregory, D.H. Preparation and characterization of tungsten oxynitride nanowires. J. Mater. Chem. 2007, 17, 4436. [CrossRef]

17. Zheng, Q.; Kvit, A.; Cai, Z.; Ma, Z.; Gong, S. A freestanding cellulose nanofibril-reduced graphene oxide-molybdenum oxynitride aerogel film electrode for all-solid-state supercapacitors with ultrahigh energy density. J. Mater. Chem. A 2017, 5, 12528-12541. [CrossRef]

18. Porto, R.L.; Frappier, R.; Ducros, J.B.B.; Aucher, C.; Mosqueda, H.; Chenu, S.; Chavillon, B.; Tessier, F.; Cheviré, F.; Brousse, T. Titanium and vanadium oxynitride powders as pseudo-capacitive materials for electrochemical capacitors. Electrochim. Acta 2012, 82, 257-262. [CrossRef]

19. Ghosh, S.; Jeong, S.M.; Polaki, S.R. A review on metal nitrides/oxynitrides as an emerging supercapacitor electrode beyond oxide. Korean J. Chem. Eng. 2018, 35, 1389-1408. [CrossRef]

20. Cheng, F.; He, C.; Shua, D.; Chen, H.; Zhang, J.; Tang, S.; Finlow, D.E. Preparation of nanocrystalline VN by the melamine reduction of V2O5 xerogel and its supercapacitive behavior. Mater. Chem. Phys. 2011, 131, 268-273. [CrossRef]

21. Choi, D.; Blomgren, G.E.; Kumta, P.N. Fast and Reversible Surface Redox Reaction in Nanocrystalline Vanadium Nitride Supercapacitors. Adv. Mater. 2006, 18, 1178-1182. [CrossRef]

22. Shu, D.; Cheng, H.; Lv, C.; Asi, M.A.; Long, L.; He, C.; Zou, X.; Kang, Z. Soft-template synthesis of vanadium oxynitride-carbon nanomaterials for supercapacitors. Int. J. Hydrog. Energy 2014, 39, 16139-16150. [CrossRef]

23. Zhou, X.; Shang, C.; Gu, L.; Dong, S.; Chen, X.; Han, P.; Li, L.; Yao, J.; Liu, Z.; Xu, H.; et al. Mesoporous Coaxial Titanium Nitride-Vanadium Nitride Fibers of CoreÀshell Structures for High-Performance Supercapacitors. ACS Appl. Mater. Interfaces 2011, 3, 3058-3063. [CrossRef] [PubMed]

24. Jacke, S.; Song, J.; Dimesso, L.; Brötz, J.; Becker, D.; Jaegermann, W. Temperature dependent phosphorous oxynitride growth for all-solid-state batteries. J. Power Sour. 2011, 196, 6911-6914. [CrossRef]

25. Ndiaye, N.M.; Sylla, N.F.; Ngom, B.D.; Barzegar, F.; Momodu, D.; Manyala, N. High-performance asymmetric supercapacitor based on vanadium dioxide/activated expanded graphite composite and carbon-vanadium oxynitride nanostructures. Electrochim. Acta 2019, 316, 19-32. [CrossRef]

26. Ndiaye, N.M.; Madito, M.J.; Ngom, B.D.; Masikhwa, T.M.; Mirghni, A.A.; Manyala, N. High-performance asymmetric supercapacitor based on vanadium dioxide and carbonized iron-polyaniline electrodes. AIP Adv. 2019, 9, 55309. [CrossRef]

27. Ndiaye, N.M.; Ngom, B.D.; Sylla, N.F.; Masikhwa, T.M.; Madito, M.J.; Momodu, D.; Ntsoane, T.; Manyala, N. Three dimensional vanadium pentoxide/graphene foam composite as positive electrode for high performance asymmetric electrochemical supercapacitor. J. Colloid Interface Sci. 2018, 532, 395-406. [CrossRef] 
28. Chhowalla, M.; Ferrari, A.C.; Robertson, J.; Amaratunga, G.A.J. Evolution of sp2 bonding with deposition temperature in tetrahedral amorphous carbon studied by Raman spectroscopy. Appl. Phys. Lett. 2000, 76, 1419. [CrossRef]

29. Roy, D.; Chhowalla, M.; Wang, H.; Sano, N.; Alexandrou, I.; Clyne, T.W.; Amaratunga, G.A.J. Characterisation of carbon nano-onions using Raman spectroscopy. Chem. Phys. Lett. 2003, 373, 52-56. [CrossRef]

30. Mohiuddin, T.M.G.; Lombardo, A.; Nair, R.R.; Bonetti, A.; Savini, G.; Jalil, R.; Bonini, N.; Basko, D.M.; Galiotis, C.; Marzari, N.; et al. Uniaxial strain in graphene by Raman spectroscopy: G peak splitting, Grüneisen parameters, and sample orientation. Phys. Rev. B Condens. Matter Mater. Phys. 2009, 79, 205433. [CrossRef]

31. Barzegar, F.; Bello, A.; Momodu, D.; Madito, M.J.; Dangbegnon, J.; Manyala, N. Preparation and characterization of porous carbon from expanded graphite for high energy density supercapacitor in aqueous electrolyte. J. Power Sour. 2016, 309, 245-253. [CrossRef]

32. Fabiane, M.; Madito, M.J.; Bello, A.; Manyala, N. Raman spectroscopy and imaging of Bernal-stacked bilayer graphene synthesized on copper foil by chemical vapour deposition: Growth dependence on temperature. J. Raman Spectrosc. 2017, 48, 639-646. [CrossRef]

33. Matsoso, B.J.; Ranganathan, K.; Mutuma, B.K.; Lerotholi, T.; Jones, G.; Coville, N.J. Synthesis and characterization of boron carbon oxynitride films with tunable composition using methane, boric acid and ammonia. New J. Chem. 2017, 41, 9497-9504. [CrossRef]

34. Nikiel, L.; Jagodzinski, P.W. Raman spectroscopic characterization of graphites: A re-evaluation of spectra/structure correlation. Carbon 1993, 31, 1313-1317. [CrossRef]

35. Yang, S.; Song, X.; Zhang, P.; Gao, L. Heating-Rate-Induced Porous $\alpha$-Fe2O3 with Controllable Pore Size and Crystallinity Grown on Graphene for Supercapacitors. ACS Appl. Mater. Interfaces 2015, 7, 75-79. [CrossRef]

36. Kafizas, A.; Hyett, G.; Parkin, I.P. Combinatorial atmospheric pressure chemical vapour deposition (cAPCVD) of a mixed vanadium oxide and vanadium oxynitride thin film. J. Mater. Chem. 2009, 19, 1399. [CrossRef]

37. Yu, J.; Wang, G.; Cheng, B.; Zhou, M. Effects of hydrothermal temperature and time on the photocatalytic activity and microstructures of bimodal mesoporous TiO2 powders. Appl. Catal. B Environ. 2007, 69, 171-180. [CrossRef]

38. Wang, Z.; Li, Z.; Zou, Z. Application of binder-free TiOxN1-x nanogrid film as a high-power supercapacitor electrode. J. Power Sour. 2015, 296, 53-63. [CrossRef]

39. Kartachova, O.; Glushenkov, A.M.; Chen, Y.; Zhang, H.; Chen, Y. Bimetallic molybdenum tungsten oxynitride: Structure and electrochemical properties. J. Mater. Chem. A 2013, 1, 7889. [CrossRef]

40. Wang, Y.; Jin, S.; Pan, G.; Li, Z.; Chen, L.; Liu, G.; Xu, X. Zr doped mesoporous LaTaON $_{2}$ for efficient photocatalytic water splitting. J. Mater. Chem. A 2019, 7, 5702-5711. [CrossRef]

41. Nada, A.A.; Bekheet, M.F.; Roualdes, S.; Gurlo, A.; Ayral, A. Functionalization of MCM-41 with titanium oxynitride deposited via PECVD for enhanced removal of methylene blue. J. Mol. Liq. 2019, 274, 505-515. [CrossRef]

42. Levchik, S.V.; Balabanovich, A.I.; Levchik, G.F.; Costa, L. Effect of melamine and its salts on combustion and thermal decomposition of polyamide 6. Fire Mater. 1997, 21, 75-83. [CrossRef]

43. Twu, J.; Shih, C.-F.; Guoa, T.-H.; Chenb, K.-H. Raman spectroscopic studies of the thermal decomposition mechanism of ammonium metavanadate. J. Mater. Chem. 1997, 7, 2273-2277. [CrossRef]

44. Selim, S.A.; Philip, C.A.; Mikhail, R.S. Thermal decomposition of ammonium metavanadate. Thermochim. Acta 1980, 36, 287-297. [CrossRef]

45. Brown, M.E.; Glasser, L.; Stewart, B.V. The thermal decomposition of ammonium metavanadate II The kinetics and mechanism of the decomposition. J. Therm. Anal. 1974, 6, 529-541. [CrossRef]

46. Gao, B.; Li, X.; Guo, X.; Zhang, X.; Peng, X.; Wang, L.; Fu, J.; Chu, P.K.; Huo, K. Nitrogen-Doped Carbon Encapsulated Mesoporous Vanadium Nitride Nanowires as Self-Supported Electrodes for Flexible All-Solid-State Supercapacitors. Adv. Mater. Interfaces 2015, 2, 1500211. [CrossRef]

47. Dwivedi, N.; Kumar, S.; Carey, J.D.; Malik, H.K. Govind Photoconductivity and characterization of nitrogen incorporated hydrogenated amorphous carbon thin films. J. Appl. Phys. 2012, 112, 113706. [CrossRef]

48. Liu, Y.; Liu, L.; Tan, Y.; Kong, L.; Kang, L.; Ran, F. Well-Dispersed Vanadium Nitride on Porous Carbon Networks Derived from Block Copolymer of PAN-b-PDMC-b-PAN Absorbed with Ammonium Metavanadate for Energy Storage Application. J. Phys. Chem. C 2018, 122, 143-149. [CrossRef] 
49. Hryha, E.; Rutqvist, E.; Nyborg, L. Stoichiometric vanadium oxides studied by XPS. Surf. Interface Anal. 2012, 44, 1022-1025. [CrossRef]

50. Ureña-Begara, F.; Crunteanu, A.; Raskin, J.P. Raman and XPS characterization of vanadium oxide thin films with temperature. Appl. Surface Sci. 2017, 403, 717-727. [CrossRef]

51. Marton, D.; Boyd, K.J.; Al-Bayati, A.H.; Todorov, S.S.; Rabalais, J.W. Carbon nitride deposited using energetic species: A two-phase system. Phys. Rev. Lett. 1994, 73, 118-121. [CrossRef] [PubMed]

52. Sevilla, M.; Fuertes, A.B. The production of carbon materials by hydrothermal carbonization of cellulose. Carbon 2009, 47, 2281-2289. [CrossRef]

53. Rantho, M.N.; Madito, M.J.; Manyala, N. Symmetric supercapacitor with supercapattery behavior based on carbonized iron cations adsorbed onto polyaniline. Electrochim. Acta 2018, 262, 82-96. [CrossRef]

54. Mutuma, B.K.; Matsoso, B.J.; Ranganathan, K.; Keartland, J.M.; Wamwangi, D.; Coville, N.J. Generation of radical species in CVD grown pristine and $\mathrm{N}$-doped solid carbon spheres using $\mathrm{H}_{2}$ and $\mathrm{Ar}$ as carrier gases. RSC Adv. 2017, 7, 21187-21195. [CrossRef]

55. Hong, Z.; Shen, B.; Chen, Y.; Lin, B.; Gao, B. Enhancement of photocatalytic H2 evolution over nitrogen-deficient graphitic carbon nitride. J. Mater. Chem. A 2013, 1, 11754. [CrossRef]

56. Fang, J.; Fan, H.; Li, M.; Long, C. Nitrogen self-doped graphitic carbon nitride as efficient visible light photocatalyst for hydrogen evolution. J. Mater. Chem. A 2015, 3, 13819-13826. [CrossRef]

57. Deng, Y.; Xie, Y.; Zou, K.; Ji, X. Review on recent advances in nitrogen-doped carbons: preparations and applications in supercapacitors. J. Mater. Chem. A 2016, 4, 1144-1173. [CrossRef]

58. Ghimbeu, C.M.; Raymundo-Piñero, E.; Fioux, P.; Béguin, F.F.; Vix-Guterl, C. Vanadium nitride/carbon nanotube nanocomposites as electrodes for supercapacitors. J. Mater. Chem. 2011, 21, 13268. [CrossRef]

59. Barzegar, F.; Bello, A.; Dangbegnon, J.K.; Manyala, N.; Xia, X. Asymmetric supercapacitor based on activated expanded graphite and pinecone tree activated carbon with excellent stability. Appl. Energy 2017, 207, 417-426. [CrossRef]

60. Mirghni, A.A.; Oyedotun, K.O.; Mahmoud, B.A.; Bello, A.; Ray, S.C.; Manyala, N. Nickel-cobalt phosphate/graphene foam as enhanced electrode for hybrid supercapacitor. Compos. Part B Eng. 2019, 174, 106953. [CrossRef]

61. Wang, Z.; Li, Z.; Feng, J.; Yan, S.; Luo, W.; Liu, J.; Yu, T.; Zou, Z. MnO2 nanolayers on highly conductive TiO0.54N0.46 nanotubes for supercapacitor electrodes with high power density and cyclic stability. Phys. Chem. Chem. Phys. 2014, 16, 8521. [CrossRef] [PubMed]

62. Yan, H.; Wang, J.; Fang, Y.; Zhou, M.; Guo, X.; Wang, H.-Q.; Dai, Y.; Li, W.; Zheng, J.-C. Porous carbon anchored titanium carbonitride for high-performance supercapacitor. Electrochim. Acta 2019, 304, 138-145. [CrossRef]

63. Sylla, N.F.; Ndiaye, N.M.; Ngom, B.D.; Momodu, D.; Madito, M.J.; Mutuma, B.K.; Manyala, N. Efect of porosity enhancing agents on the electrochemical performance of high-energy ultracapacitor electrodes derived from peanut shell waste. Sci. Rep. 2019, 9, 13673. [CrossRef] [PubMed]

(C) 2019 by the authors. Licensee MDPI, Basel, Switzerland. This article is an open access article distributed under the terms and conditions of the Creative Commons Attribution (CC BY) license (http://creativecommons.org/licenses/by/4.0/). 